Prepared in cooperation with the

Maryland Department of the Environment

and the

Maryland Department of Natural Resources

\title{
A Science Plan for a Comprehensive Assessment of Water Supply in the Region Underlain by Fractured Rock in Maryland
}

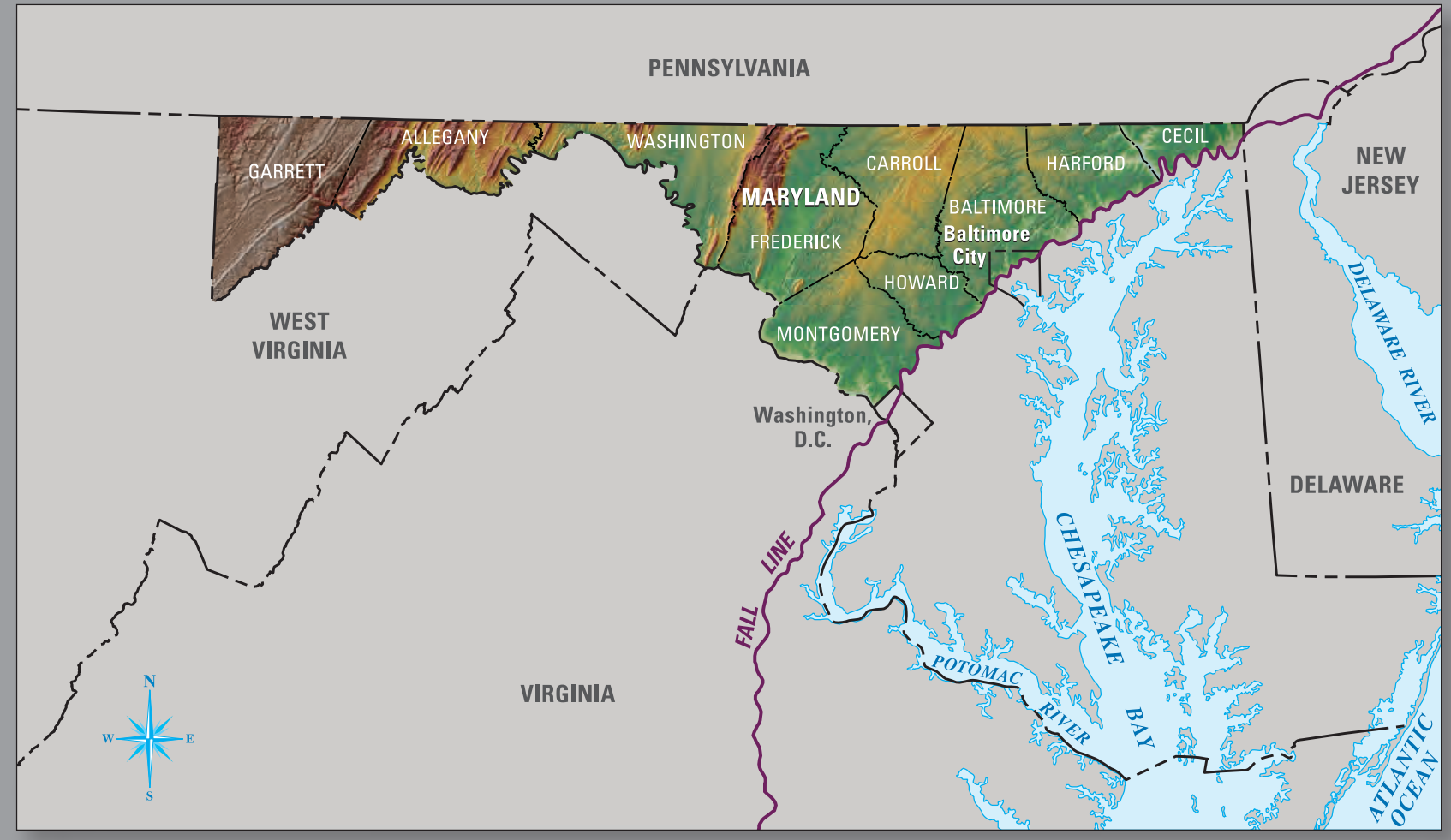

Scientific Investigations Report 2012-5160

U.S. Department of the Interior

U.S. Geological Survey 
Cover. Map showing the region underlain by fractured rock in Maryland. 


\section{A Science Plan for a Comprehensive Assessment of Water Supply in the Region Underlain by Fractured Rock in Maryland}

By Brandon J. Fleming, Patrick A. Hammond, Scott A. Stranko, Mark T. Duigon, and Saeid Kasraei

Prepared in cooperation with the

Maryland Department of the Environment and the

Maryland Department of Natural Resources

Scientific Investigations Report 2012-5160 


\section{U.S. Department of the Interior \\ KEN SALAZAR, Secretary \\ U.S. Geological Survey \\ Marcia K. McNutt, Director}

U.S. Geological Survey, Reston, Virginia: 2012

For more information on the USGS - the Federal source for science about the Earth, its natural and living resources, natural hazards, and the environment, visit http://www.usgs.gov or call 1-888-ASK-USGS

For an overview of USGS information products, including maps, imagery, and publications, visit http://www.usgs.gov/pubprod

To order this and other USGS information products, visit http://store.usgs.gov

Any use of trade, product, or firm names is for descriptive purposes only and does not imply endorsement by the U.S. Government.

Although this information product, for the most part, is in the public domain, it also may contain copyrighted materials as noted in the text. Permission to reproduce copyrighted items must be secured from the copyright owner.

Suggested citation:

Fleming, B.J., Hammond, P.A., Stranko, S.A., Duigon, M.T., and Kasraei, Saeid, 2012, A science plan for a comprehensive assessment of water supply in the region underlain by fractured rock in Maryland: U.S. Geological Survey Scientific Investigations Report 2012-5160, 29 p 


\section{Contents}

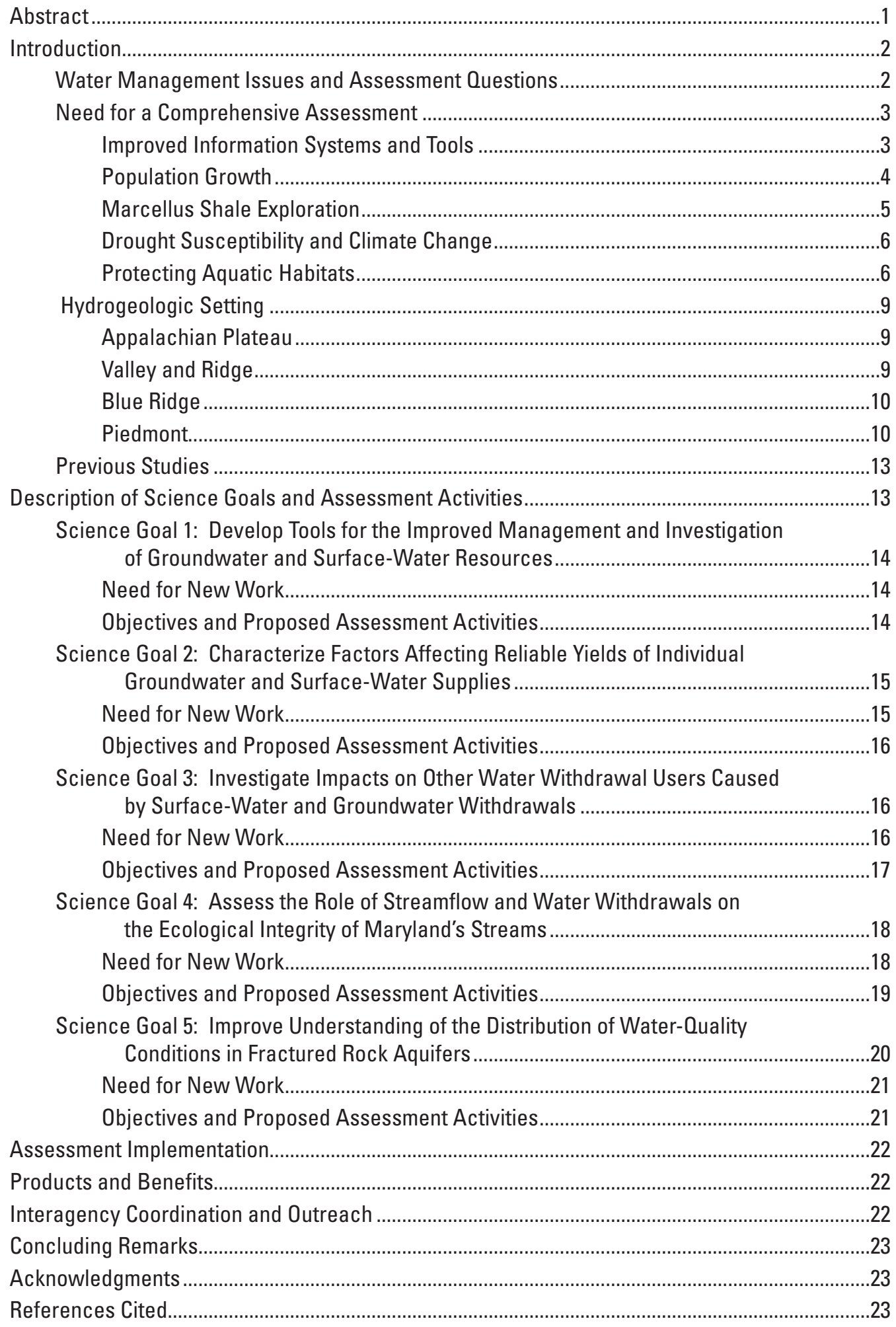




\section{Figures}

1. Map showing counties within study area for a comprehensive assessment of water supply in the region underlain by fractured rock in Maryland...

2. Graph showing 2005 water withdrawals for all counties in the fracturedrock area of Maryland by water-use category.

3. Map showing projected population increase in Maryland by county from 2010 to 2040

4. Map and graphs showing $(A)$ central Maryland and hydrographs of groundwater levels for (B) water-table well BA Ea 18, Baltimore County, (C) water-table well FR Df 35, Frederick County, and streamflow for (D) Bennett Creek (01643500), and (E) North Branch Patapsco River at Cedarhurst, Md. (01586000).

5. Graph showing example flow-ecology response curves showing relations between alterations in streamflow and ecological conditions for $(A)$ linear, $(B)$ critical thresholds, and $(C)$ non-linear curves

6. Map and diagrams showing $(A)$ physiographic provinces and conceptual groundwater-flow diagrams for $(B)$ carbonate rocks, $(C)$ coal-bearing rocks in the Appalachian Plateau, (D) crystalline rocks in the Piedmont Uplands, and (E) Mesozoic basin in the Piedmont Lowlands

7. Map showing location of the Maryland Biological Stream Survey Sentinel sites

\section{Tables}

1. Projected population increase in Maryland by county from 2010 to 2040 ........................5

2. Percent of population served by domestic groundwater wells for each county in the fractured-rock region of Maryland, 2005. 


\section{Conversion Factors and Datums}

\begin{tabular}{|c|c|c|}
\hline Multiply & By & To obtain \\
\hline \multicolumn{3}{|c|}{ Length } \\
\hline foot $(\mathrm{ft})$ & 0.3048 & meter $(\mathrm{m})$ \\
\hline mile (mi) & 1.609 & kilometer $(\mathrm{km})$ \\
\hline \multicolumn{3}{|c|}{ Area } \\
\hline square foot $\left(\mathrm{ft}^{2}\right)$ & 0.09290 & square meter $\left(\mathrm{m}^{2}\right)$ \\
\hline square mile $\left(\mathrm{mi}^{2}\right)$ & 2.590 & square kilometer $\left(\mathrm{km}^{2}\right)$ \\
\hline \multicolumn{3}{|c|}{ Volume } \\
\hline gallon (gal) & 0.003785 & cubic meter $\left(\mathrm{m}^{3}\right)$ \\
\hline million gallons (Mgal) & 3,785 & cubic meter $\left(\mathrm{m}^{3}\right)$ \\
\hline cubic foot $\left(\mathrm{ft}^{3}\right)$ & 0.02832 & cubic meter $\left(\mathrm{m}^{3}\right)$ \\
\hline \multicolumn{3}{|c|}{ Flow rate } \\
\hline foot per day $(\mathrm{ft} / \mathrm{d})$ & 0.3048 & meter per day $(\mathrm{m} / \mathrm{d})$ \\
\hline cubic foot per second $\left(\mathrm{ft}^{3} / \mathrm{s}\right)$ & 0.02832 & cubic meter per second $\left(\mathrm{m}^{3} / \mathrm{s}\right)$ \\
\hline cubic foot per day $\left(\mathrm{ft}^{3} / \mathrm{d}\right)$ & 0.02832 & cubic meter per day $\left(\mathrm{m}^{3} / \mathrm{d}\right)$ \\
\hline gallon per minute (gal/min) & 0.06309 & liter per second $(\mathrm{L} / \mathrm{s})$ \\
\hline gallon per day (gal/d) & 0.003785 & cubic meter per day $\left(\mathrm{m}^{3} / \mathrm{d}\right)$ \\
\hline million gallons per day (Mgal/d) & 0.04381 & cubic meter per second $\left(\mathrm{m}^{3} / \mathrm{s}\right)$ \\
\hline \multicolumn{3}{|c|}{ Specific capacity } \\
\hline gallon per minute per foot & 0.2070 & liter per second per meter $[(\mathrm{L} / \mathrm{s}) / \mathrm{m}]$ \\
\hline \multicolumn{3}{|c|}{ Hydraulic conductivity } \\
\hline foot per day $(\mathrm{ft} / \mathrm{d})$ & 0.3048 & meter per day $(\mathrm{m} / \mathrm{d})$ \\
\hline \multicolumn{3}{|c|}{ Transmissivity* $^{*}$} \\
\hline foot squared per day $\left(\mathrm{ft}^{2} / \mathrm{d}\right)$ & 0.09290 & meter squared per day $\left(\mathrm{m}^{2} / \mathrm{d}\right)$ \\
\hline
\end{tabular}

Temperature in degrees Fahrenheit $\left({ }^{\circ} \mathrm{F}\right)$ may be converted to degrees Celsius $\left({ }^{\circ} \mathrm{C}\right)$ as follows:

$$
{ }^{\circ} \mathrm{C}=\left({ }^{\circ} \mathrm{F}-32\right) / 1.8
$$

Vertical coordinate information is referenced to the North American Vertical Datum of 1988 (NAVD 88).

Horizontal coordinate information is referenced to the North American Datum of 1983 (NAD 83).

Altitude, as used in this report, refers to distance above the vertical datum.

*Transmissivity: The standard unit for transmissivity is cubic foot per day per square foot times foot of aquifer thickness $\left[\left(\mathrm{ft}^{3} / \mathrm{d}\right) / \mathrm{ft}^{2}\right] \mathrm{ft}$. In this report, the mathematically reduced form, foot squared per day $\left(\mathrm{ft}^{2} / \mathrm{d}\right)$, is used for convenience. 


\section{Abbreviations}

$\begin{array}{ll}\text { BIBI } & \text { Benthic Macroinvertebrate Index of Biotic Integrity } \\ \text { MDDNR } & \text { Maryland Department of Natural Resources } \\ \text { ELOHA } & \text { Ecological Limits of Hydrologic Alteration } \\ \text { FIBI } & \text { Fish Index of Biotic Integrity } \\ \text { FR-AIS } & \text { Fractured Rock Aquifer Information System } \\ \text { GIS } & \text { Geographic Information System } \\ \text { HIP } & \text { Hydroecological Integrity Assessment Process } \\ \text { ICPRB } & \text { Interstate Commission on the Potomac River Basin } \\ \text { MANTA } & \text { Monitoring and Non-Tidal Assessment Division (MDDNR) } \\ \text { MBSS } & \text { Maryland Biological Stream Survey } \\ \text { MCL } & \text { Maximum Contaminant Level (USEPA) } \\ \text { MDE } & \text { Maryland Department of the Environment } \\ \text { MDE WSP } & \text { Maryland Department of the Environment Water Supply Program } \\ \text { MGS } & \text { Maryland Geological Survey } \\ \text { NAW0A } & \text { National Water-Quality Assessment Program (USGS) } \\ \text { NWIS } & \text { National Water Information System } \\ \text { PDWIS } & \text { Public Drinking Water Information System } \\ \text { USEPA } & \text { U.S. Environmental Protection Agency } \\ \text { USGS } & \text { U.S. Geological Survey } \\ \text { 7010 } & \text { 7-day, 10-year low flow }\end{array}$




\title{
A Science Plan for a Comprehensive Assessment of Water Supply in the Region Underlain by Fractured Rock in Maryland
}

\author{
By Brandon J. Fleming', Patrick A. Hammond², Scott A. Stranko ${ }^{3}$, Mark T. Duigon ${ }^{4}$, and Saeid Kasraei²
}

\section{Abstract}

The fractured rock region of Maryland, which includes land areas north and west of the Interstate 95 corridor, is the source of water supply for approximately 4.4 million Marylanders, or approximately 76 percent of the State's population. Whereas hundreds of thousands of residents rely on wells (both domestic and community), millions rely on surface-water sources. In this region, land use, geology, topography, water withdrawals, impoundments, and other factors affect water-flow characteristics. The unconfined groundwater systems are closely interconnected with rivers and streams, and are affected by seasonal and climatic variations. During droughts, groundwater levels drop, thereby decreasing well yields, and in some cases, wells have gone dry. Low groundwater levels contribute to reduced streamflows, which in turn, can lead to reduced habitat for aquatic life. Increased demand, over-allocation, population growth, and climate change can affect the future sustainability of water supplies in the region of Maryland underlain by fractured rock.

In response to recommendations of the 2008 Advisory Committee on the Management and Protection of the State's Water Resources report, the Maryland Department of the Environment's Water Supply Program, the Maryland Geological Survey, the Maryland Department of Natural Resources, Monitoring and Non-Tidal Assessment (MANTA) Division, and the U.S. Geological Survey have developed a science plan for a comprehensive assessment that will provide new scientific information, new data analysis, and new tools for the State to better manage water resources in the fractured rock region of Maryland. The science plan lays out five goals for the comprehensive assessment: (1) develop tools for the

\footnotetext{
${ }^{1}$ U.S. Geological Survey

${ }^{2}$ Maryland Department of the Environment

${ }^{3}$ Maryland Department of Natural Resources

${ }^{4}$ Formerly of Maryland Geological Survey
}

improved management and investigation of groundwater and surface-water resources; (2) characterize factors affecting reliable yields of individual groundwater and surface-water supplies; (3) investigate impacts on nearby water withdrawal users caused by groundwater and surface-water withdrawals; (4) assess the role of streamflow and water withdrawals on the ecological integrity of streams; and (5) improve understanding of the distribution of water-quality conditions in fractured rock aquifers. To accomplish these goals, accurate data collection, review, and analysis are needed, including the study of "Research Watersheds" that can provide detailed information about the potential effects that climate change and water withdrawals may have on groundwater, streamflow, and aquatic life.

The assessment planning started in 2009 and is being conducted with close interagency coordination. A Fractured Rock Aquifer Information System is currently (2012) undergoing initial development. Other major tasks that will be performed include the development of work plans for each science goal, the estimation of daily streamflow at ungaged streams, and the design and implementation of Research Watersheds. Finally, scenarios will be modeled to evaluate current water allocation permitting methodologies, investigate effects on nearby water withdrawal users caused by groundwater and surface-water withdrawals, and assess the potential impacts of climate change on water resources.

Desktop and Web-based tools will be developed in order to meet the diverse research needs of the assessment. These tools, including the Fractured Rock Aquifer Information System will be continuously improved during the assessment to store relevant groundwater and surface-water data in spatially referenced databases, estimate streamflows, locate higher-yielding wells, estimate the impacts of withdrawals on nearby users, and assess the cumulative impacts of withdrawals on the aquatic resource. Tools will be developed to serve the needs of many audiences, including water resource managers, water suppliers, planners, policymakers, and other scientific investigators. 


\section{Introduction}

The Maryland Department of the Environment (MDE) is responsible for managing the State's water resources through a permitting program that has been in place since the 1930s. The program has evolved through legislative action and scientific advances. In 2008, the Advisory Committee on the Management and Protection of the State's Water Resources, which was established by an Executive Order of the Governor, completed its review of the State's program and issued its final report, outlining a number of recommendations to assist the State in better meeting its obligations. The Committee identified the need for accurate, comprehensive data to support planning, management, and permitting decisions, and recommended that the State conduct studies in both the Coastal Plain and fractured rock regions of Maryland. The investigations that are planned will provide the data and scientific tools needed to ensure that water is allocated and used in a sustainable manner, while minimizing adverse impacts to water supplies and aquatic ecosystems. In response to the Advisory Committee's recommendations, MDE has formed an interagency partnership with the Maryland Department of Natural Resources (MDDNR) Maryland Geological Survey (MGS), Monitoring and Non-Tidal Assessments (MANTA) Division, and the U.S. Geological Survey (USGS), to oversee and conduct this study of the fractured rock region. The fractured rock region of Maryland (fig.1), which includes land areas north and west of the Interstate 95 corridor, is the source of water supply for approximately 4.4 million Marylanders, or approximately 76 percent of the State's population. The majority of water use is for thermoelectric (electricity produced by steamdriven turbine generators) and public supply (fig. 2). Whereas hundreds of thousands of residents rely on wells (both domestic and community), millions rely on surface-water sources.

This Science Plan describes the goals of the Fractured Rock study and presents the general methods for conducting the study. This Science Plan also presents guidelines for conducting a comprehensive assessment of the water supply resources in the region of Maryland underlain by fractured rock aquifers. It describes the scientific and water management issues motivating the comprehensive assessment, science goals, objectives within each goal, and potential implementation activities. To prudently manage the water resources of Maryland, it is imperative to gain an improved understanding of the interactions between surface and subsurface water resources in the fractured rock region. This is a vital aspect of the study, as this understanding is essential for the preservation of Maryland's water supplies, the ecological health of streams, and planning for potential climate change impacts on water resource availability.

Once completed, the comprehensive assessment will provide the State with improved scientific knowledge and tools that will assist in the management of water resources, the use of science-based policies for water allocation, and heightened preparedness for climate variation. Results of the assessment will also guide water suppliers in selecting additional water sources, and water-supply planning efforts, which are a critical component to future growth and development in the State.

\section{Water Management Issues and Assessment Questions}

In Maryland, surface-water and groundwater withdrawals over 10,000 gallons per day are managed by MDE through the Water Supply Program. Permit applications are evaluated to ensure that the amount of the withdrawal is reasonable, that the proposed withdrawal will not jeopardize the State's natural resources, and impacts on other water users (including nearby private, commercial, and industrial withdrawals) are not unreasonable. In the region underlain by fractured rock, MDE has used various methods to evaluate the reasonableness of proposed water withdrawals.

For groundwater uses, data from water-level monitoring during aquifer tests and fracture trace analyses are most commonly evaluated to aid in the determination of well yield, the assessment of potential impacts on other users, and the need and location of future water-level monitoring. Water balance calculations are utilized to ensure aquifer sustainability and the protection of stream base flow. In the case of proposed surface-water withdrawals, available streamgage data from the USGS are used to conduct mass-flow and frequency-flow analyses. These analyses determine reliable reservoir yields, adequacy of off-stream storage or back-up supplies for withdrawals through simple intakes (direct extraction from stream or water body), and necessary flow-by or seasonally adjusted flow releases required to protect downstream users and aquatic habitats.

Decisions regarding the management of the State's water supply must be based on sound, comprehensive knowledge and assessment techniques. Making these decisions requires foresight into issues that currently (2012), or could potentially, affect the State. Some of the issues specifically considered during the development of this Plan included:

- How can the scientific methods for evaluating water allocation permits be improved?

- How will Maryland's population growth and new natural gas resource extraction methods affect water supply and demand?

- How will water availability be affected by droughts that are potentially longer, more frequent, and more intense as a result of climate change?

- What streamflows are necessary to ensure ecological integrity of streams?

- How can water suppliers and water resource managers identify the best locations for wells to ensure sustainable use? 
- What is the distribution of regulated drinking-waterquality constituents in areas where residents rely on private water wells?

To address these questions, new data-management systems and tools will need to be developed. New hydrologic data will need to be collected in order to update and enhance tools developed during this assessment. These tools will be used primarily by water managers and scientists, and will also be made available to planners, decision makers, local governments, and the public.

\section{Need for a Comprehensive Assessment}

Understanding the factors related to groundwater availability in central and western Maryland is an important component of water resources management. Because stream base flow is derived entirely from groundwater discharge, factors affecting groundwater availability will have a direct bearing on streamflow (Wolman, 2008). This study will attempt to identify factors that influence current and future groundwater availability and ecological flow needs.

\section{Improved Information Systems and Tools}

MDE water resource managers have been issuing water withdrawal permits in fractured rock aquifers using the watershed water balance method modified from Willey and Achmad (1986) as one component of their analysis for nearly 20 years. The water balance method is used to determine if the requested withdrawal is reasonable to maintain the resource and to evaluate reserves for future allocations. Although this method has served the State well, it does not account for seasonal variability because it is based on an annual recharge rate during a drought. Therefore, objective scientific comparisons and evaluations of known methods and practices are needed. Comparisons of results from aquifer tests with production capacities have shown the difficulty in correctly estimating future well performance. Applicants often have overestimated well yields from the aquifer test results. Standard methods for interpreting test results need to be published to ensure that the public interest is protected.

This comprehensive assessment is designed to provide information and tools to improve permitting methods and the determination of sustainable allocation quantities. In addition,

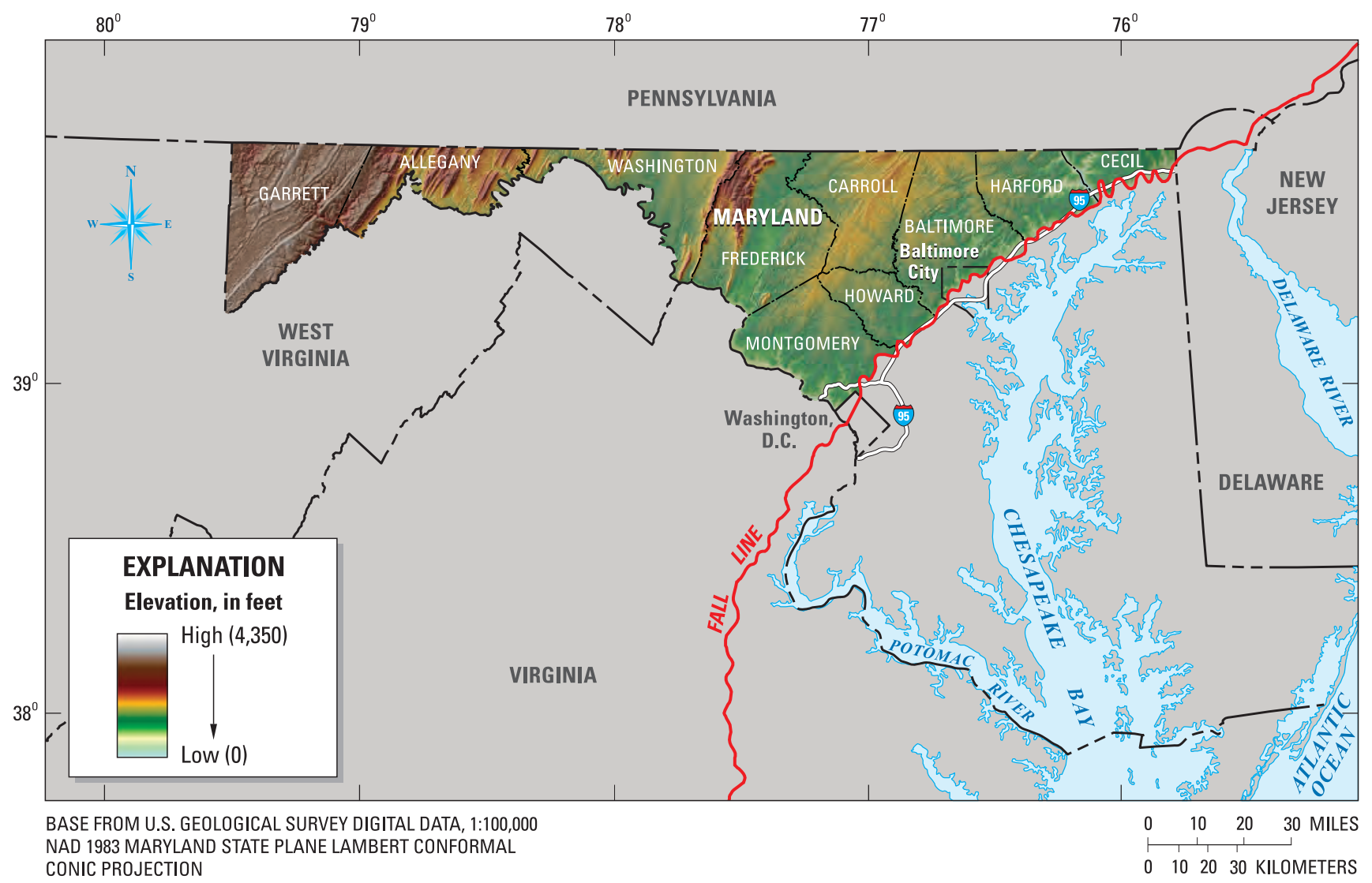

Figure 1. Counties within study area for a comprehensive assessment of water supply in the region underlain by fractured rock in Maryland. 


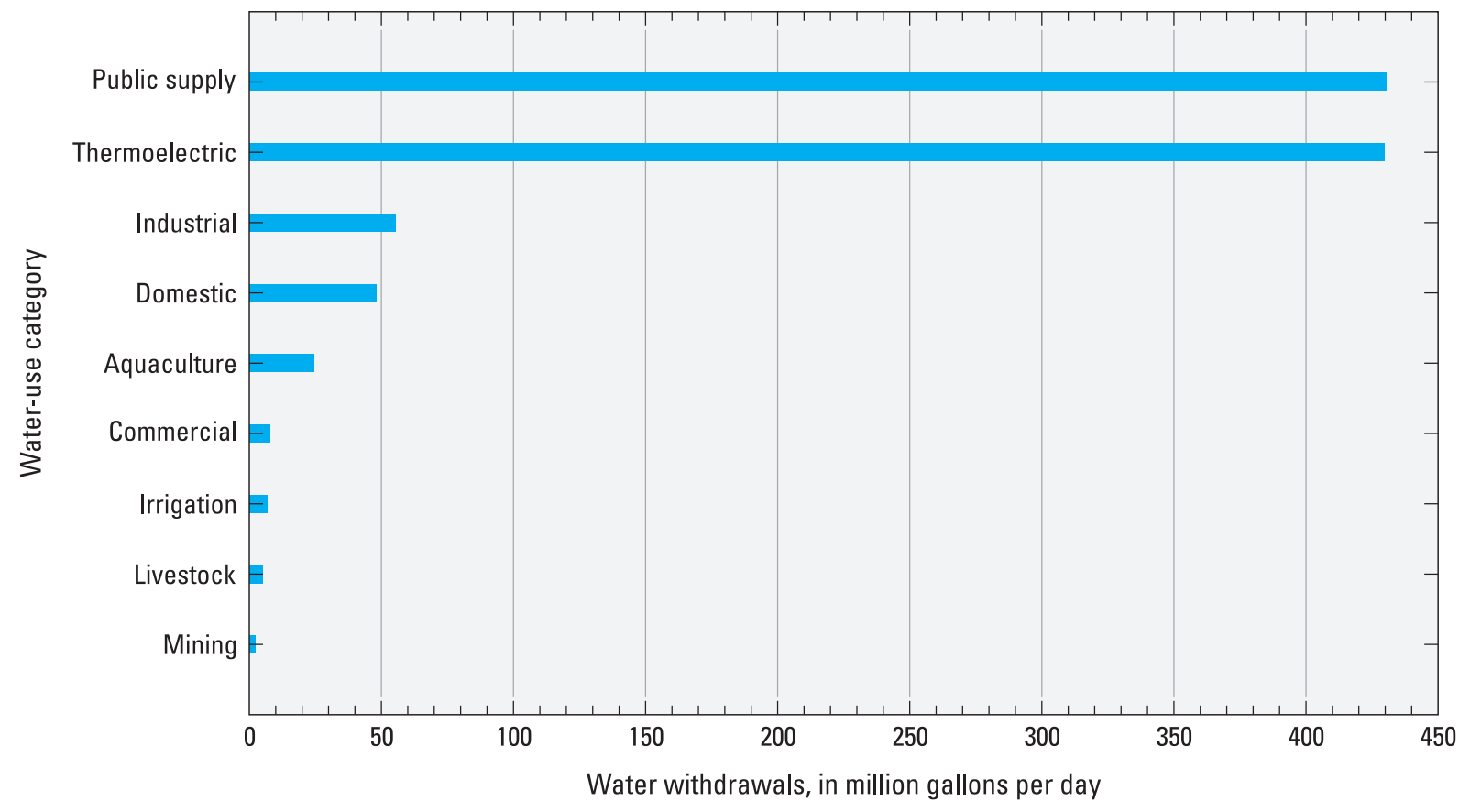

Figure 2. 2005 water withdrawals for all counties in the fractured-rock area of Maryland by water-use category (Susan Hutson, U.S. Geological Survey, written commun., 2012).

there is a need for the increased accessibility of geospatially referenced data for permit managers. The necessary enhancements to datasets include water quality, current permitted allocations and water-use data, aquifer test data, hydrogeologic data, and flow data at ungaged streams.

Water resource managers rely on data and information from many sources to make decisions on water allocations and future supply plans. They have expressed the need for a computerized system that will allow them to access all available data, and to summarize, graphically display, and visualize the data and interpretive information for specific areas of interest. A computerized system will allow managers to evaluate water allocations on a seasonal basis and at a sub-watershed scale to provide improved estimates of water availability. In addition, new modeling tools are needed to evaluate current and updated methods for determining the impacts of water allocations to assure that decisions are made from the best available science and information. Numerical modeling techniques have greatly improved over the last decade, and now incorporate both surface-water and groundwater programs capable of providing a more comprehensive representation of watershed water budgets.

\section{Population Growth}

The surface-water and groundwater resources in the fractured rock region are crucial to the State of Maryland (Bolton and others, 2009). The demand for water generally increases in proportion to population growth, which then increases pressure on water supplies. According to the 2010 U.S. Census, the population of Maryland has increased by over 500,000 since 2000 to 5.8 million people in 2010. The Maryland Department of Planning projects that by 2040 , the State's total population will be approximately 6.9 million, representing a growth rate of almost 20 percent over the 30 -year period.

The spatial distribution of projected population growth from 2000 to 2040 is uneven in the fractured rock region of Maryland (fig. 3). The largest growth rates are expected to occur in Frederick and Cecil Counties at 57 and 62 percent, respectively. Counties east of Frederick (Carroll, Harford, Howard, and Montgomery) are expected to see a growth rate averaging 26 percent. In addition, Harford County is projected to undergo a population increase of 22 percent by 2040 . Over this period, Baltimore County is expected to grow by about 8 percent, while Allegany and Garrett Counties are projected to expand more slowly, growing at rates of 3 and 7 percent, respectively (table 1).

The anticipated increase in water demand will stress aquifer systems and surface-water supplies in Maryland. Resource managers must ensure that the effects of new surface-water and groundwater withdrawals on other water users are minimal. This includes impacts to streamflow and nearby groundwater wells. Communities are already challenged to plan for growth. In some cases, a viable water supply can be the limiting factor for continued growth. 


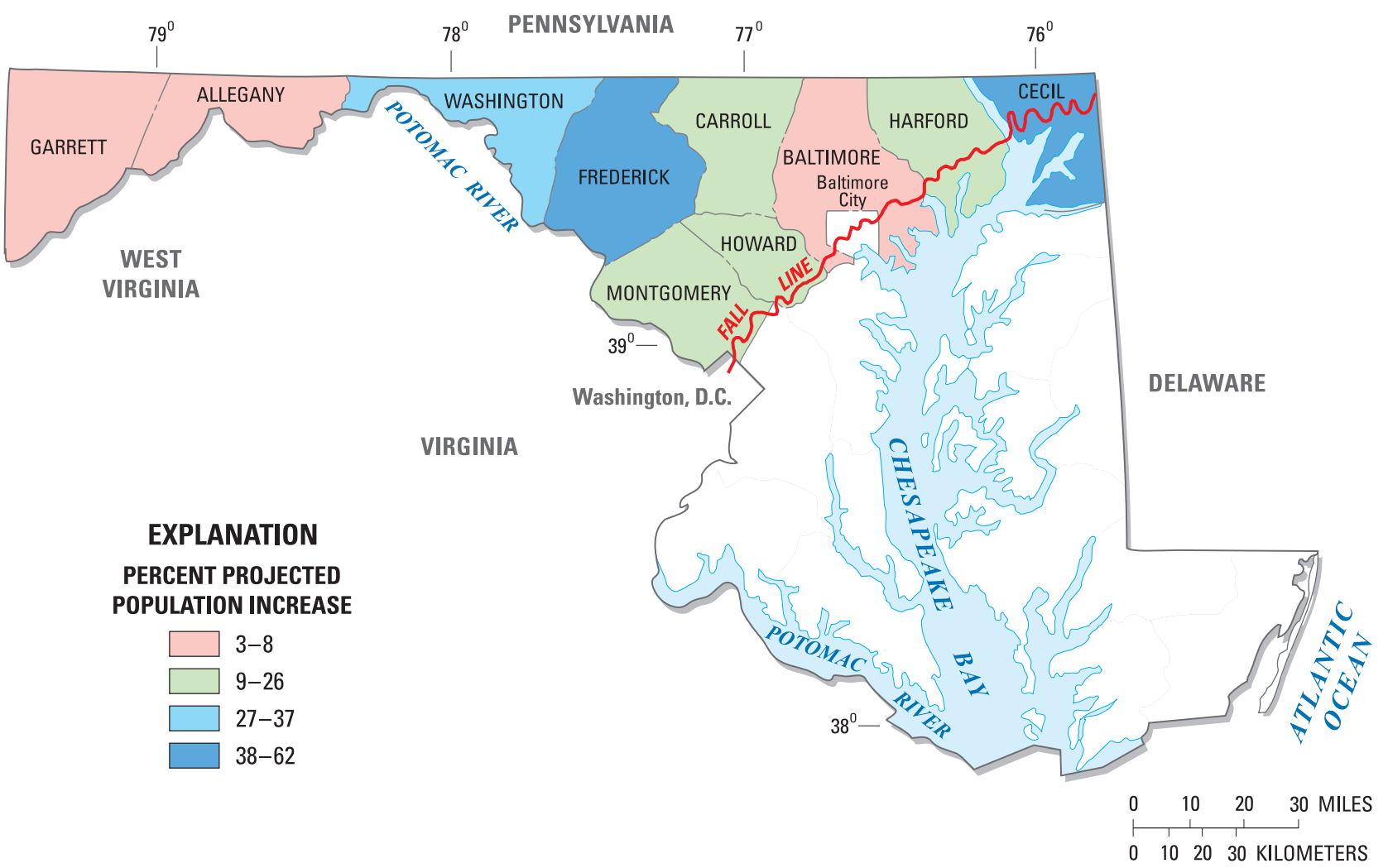

Figure 3. Projected population increase in Maryland by county from 2010 to 2040 (Maryland Department of Planning, 2010).

Table 1. Projected population increase in Maryland by county from 2010 to 2040.

\begin{tabular}{lc}
\hline County & $\begin{array}{c}\text { Projected population increase } \\
\text { from 2010 to 2040 } \\
\text { (percent) }\end{array}$ \\
\hline Cecil & 62 \\
\hline Frederick & 57 \\
\hline Washington & 37 \\
\hline Carroll & 26 \\
\hline Montgomery & 22 \\
\hline Harford & 22 \\
\hline Howard & 18 \\
\hline Baltimore & 8 \\
\hline Garrett & 7 \\
\hline Allegany & 3 \\
\hline
\end{tabular}

${ }^{1}$ Maryland Department of Planning, 2010.

\section{Marcellus Shale Exploration}

Gas exploration in the Marcellus Shale has occurred in both Pennsylvania to the north and West Virginia to the south and west of Maryland's Garrett and Allegany Counties. Concerns over the availability of water for extracting natural gas have been well documented across the Mid-Atlantic region. Maryland's Governor, Martin O'Malley, issued an Executive Order on June 6, 2011 establishing an Advisory Commission to undertake a study of the extraction of natural gas from shale formations. One component of the study addresses the water resources required to support hydraulic fracturing (hydrofracking) activities, whereas other components address potential water-quality impacts. The amount of water necessary for hydraulic fracturing of one well averaged over 2.5 million gallons (Susquehanna River Basin Commission, 2010). Water managers need to be prepared to assess the aggregate and cumulative impacts of these new operations. 


\section{Drought Susceptibility and Climate Change}

Climatic variations affect water supplies more directly and more immediately in Maryland's fractured rock region than in the Coastal Plain because of the interconnected nature of the unconfined groundwater systems to rivers and streams in the fractured rock region. The hydrologic relation among climate, surface water, and groundwater was evident during the droughts of 1999 and 2002 when groundwater and streamflow were at their lowest levels in decades as a result of significant below-normal recharge from a lack of precipitation (fig. 4).

Surface water and groundwater systems can respond differently to drought conditions, even though they are often studied as a single resource (Winter and others, 1998). The timing and magnitude of declines in streamflow and groundwater levels in response to drought conditions are poorly understood. Geology and landscape characteristics are important factors affecting drought response in streams and aquifers. The heterogeneous nature of the fractured rock in Maryland can increase the variability of hydrologic response to drought across the region for comprehensive assessment.

Increases in interannual precipitation variability and more frequent and intense extreme events have been observed globally (Bates and others, 2008). The effects of global climate change on Maryland's water resources are unknown, but possible impacts include more frequent and longer droughts and more frequent and severe storms (Boicourt and Johnson, 2010). To better protect and manage Maryland's water resources, and prepare for the effects of drought and climate variability, a better understanding of the interactions between climate, streams, and aquifers in the fractured rock region of Maryland is needed.

\section{Protecting Aquatic Habitats}

Scientists, water resource managers, and policy makers need to understand the characteristics of streamflow that must be maintained to ensure the persistence of the full complement of biological taxa and prevent the degradation of the ecological integrity of Maryland streams. There is a need for a greater understanding of the sensitivity of various species to alterations in natural flow regimes. Although biological inventories and streamflow records have been collected from Maryland streams for many years, the relations between streamflow and biological taxa are not well understood. A framework for the necessary analyses has been developed (Poff and others, 1997) for the different flow-ecology thresholds (fig. 5), but the relation between hydrologic alteration and ecological condition varies greatly and is not yet defined for streams in Maryland.

\section{A. Central Maryland}

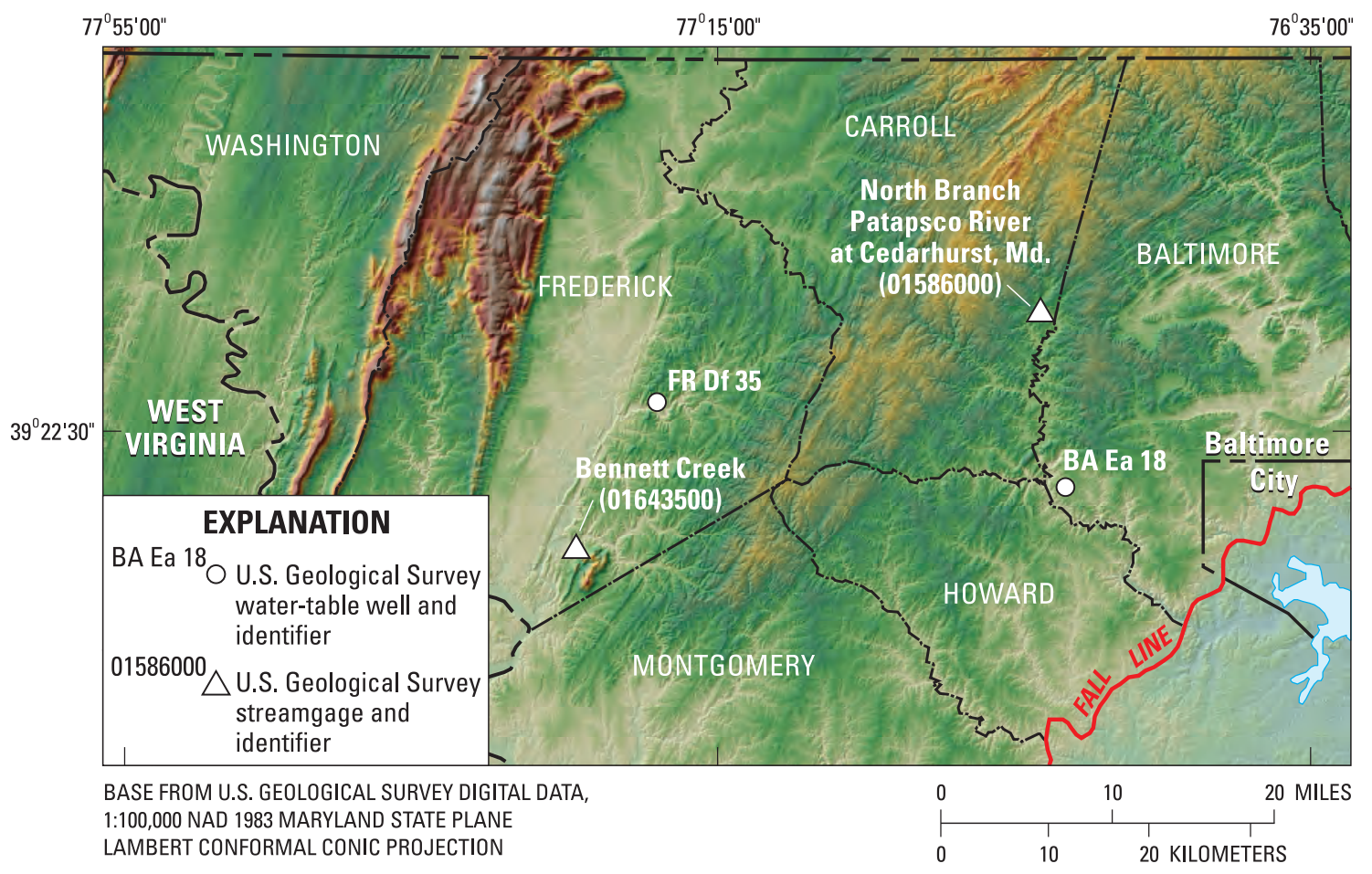

Figure 4. (A) central Maryland and hydrographs of groundwater levels for (B) water-table well BA Ea 18, Baltimore County, (C) water-table well FR Df 35, Frederick County, and streamflow for (D) Bennett Creek (01643500), and (E) North Branch Patapsco River at Cedarhurst, Md. (01586000). 
B. Water-table well BA Ea 18, Baltimore County

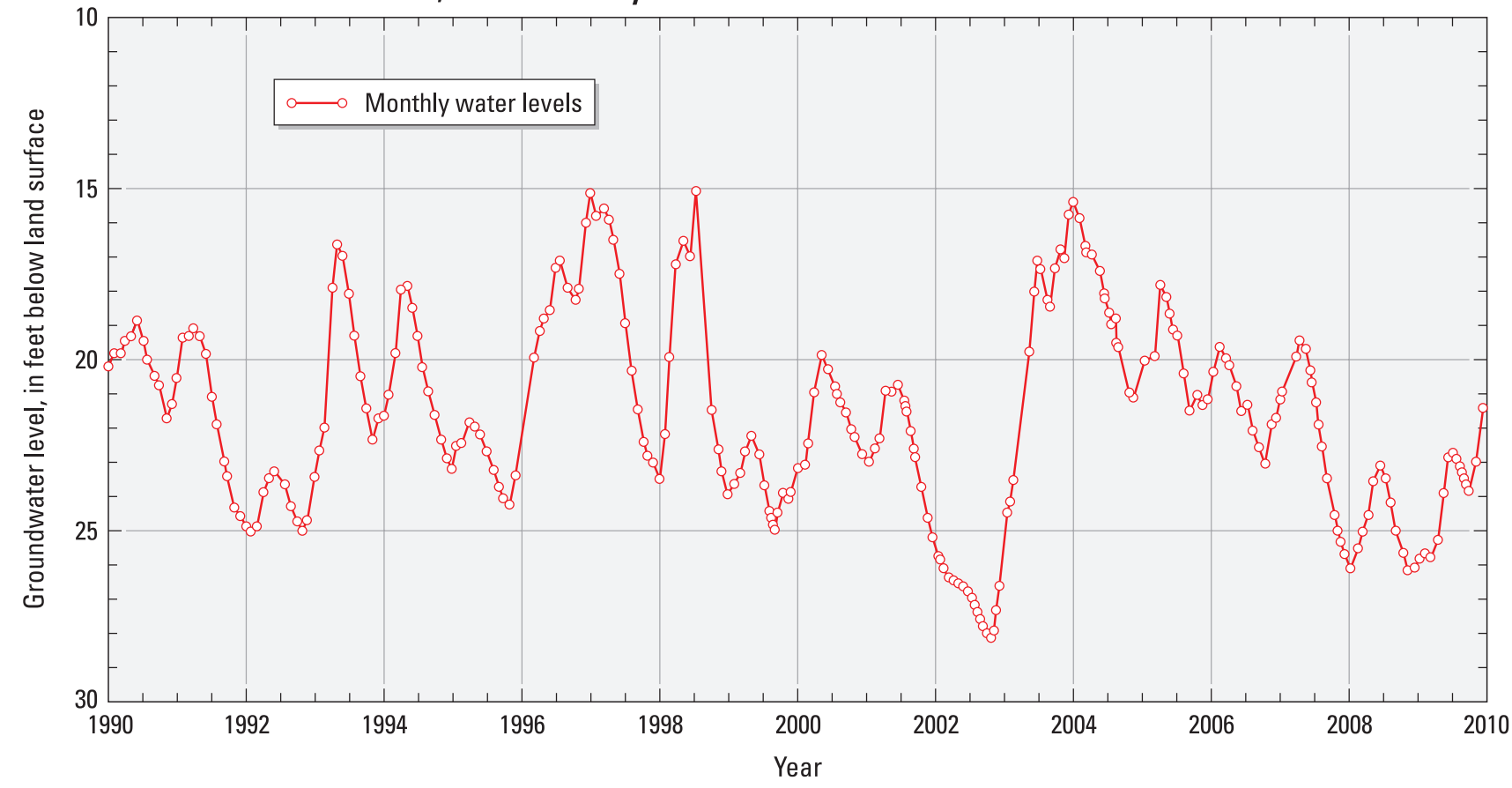

C. Water-table well FR Df 35, Frederick County

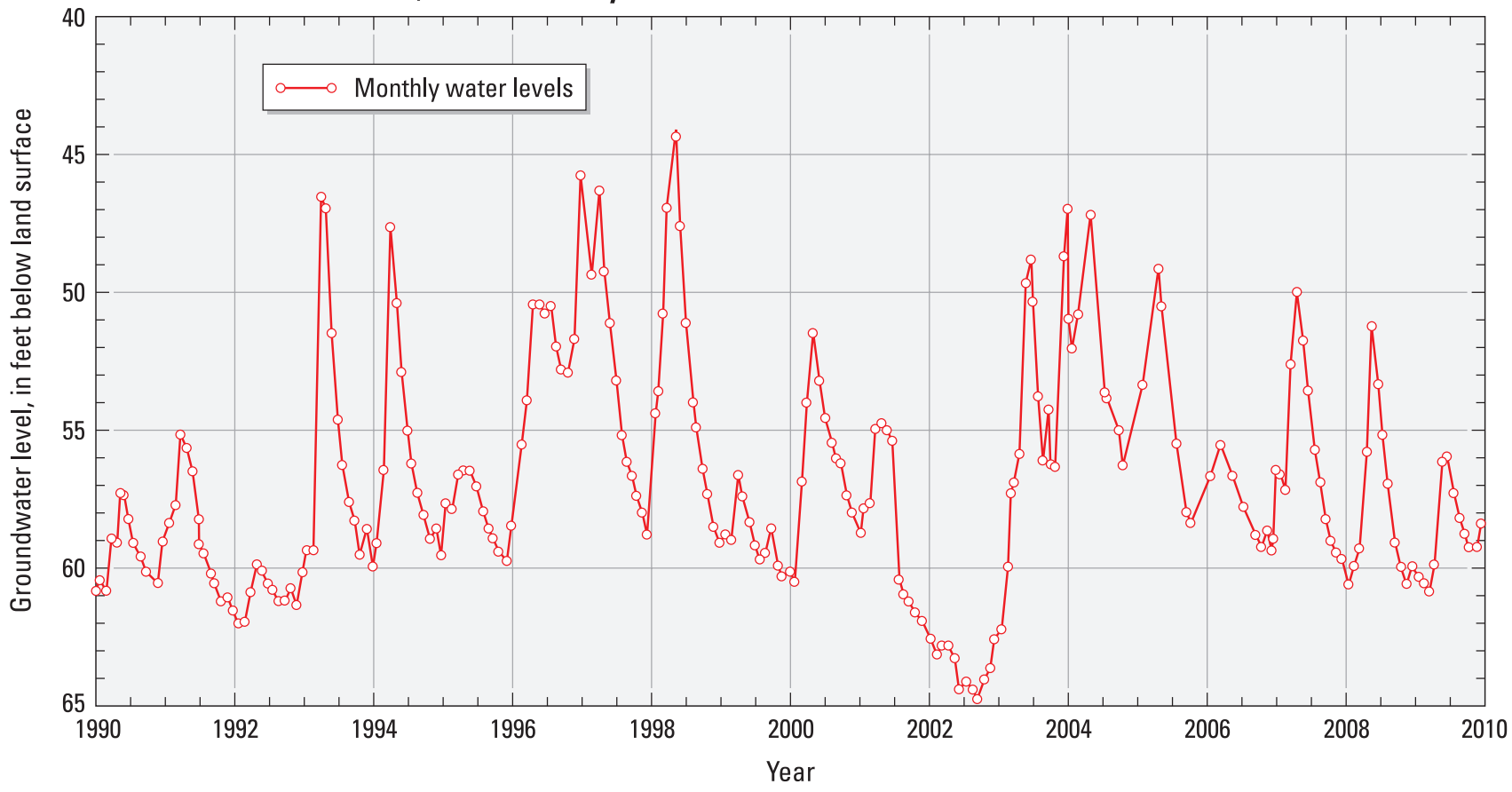

Figure 4. (A) central Maryland and hydrographs of groundwater levels for (B) water-table well BA Ea 18, Baltimore County, (C) water-table well FR Df 35, Frederick County, and streamflow for (D) Bennett Creek (01643500), and (E) North Branch Patapsco River at Cedarhurst, Md. (01586000).-Continued 


\section{Bennett Creek (01643500)}
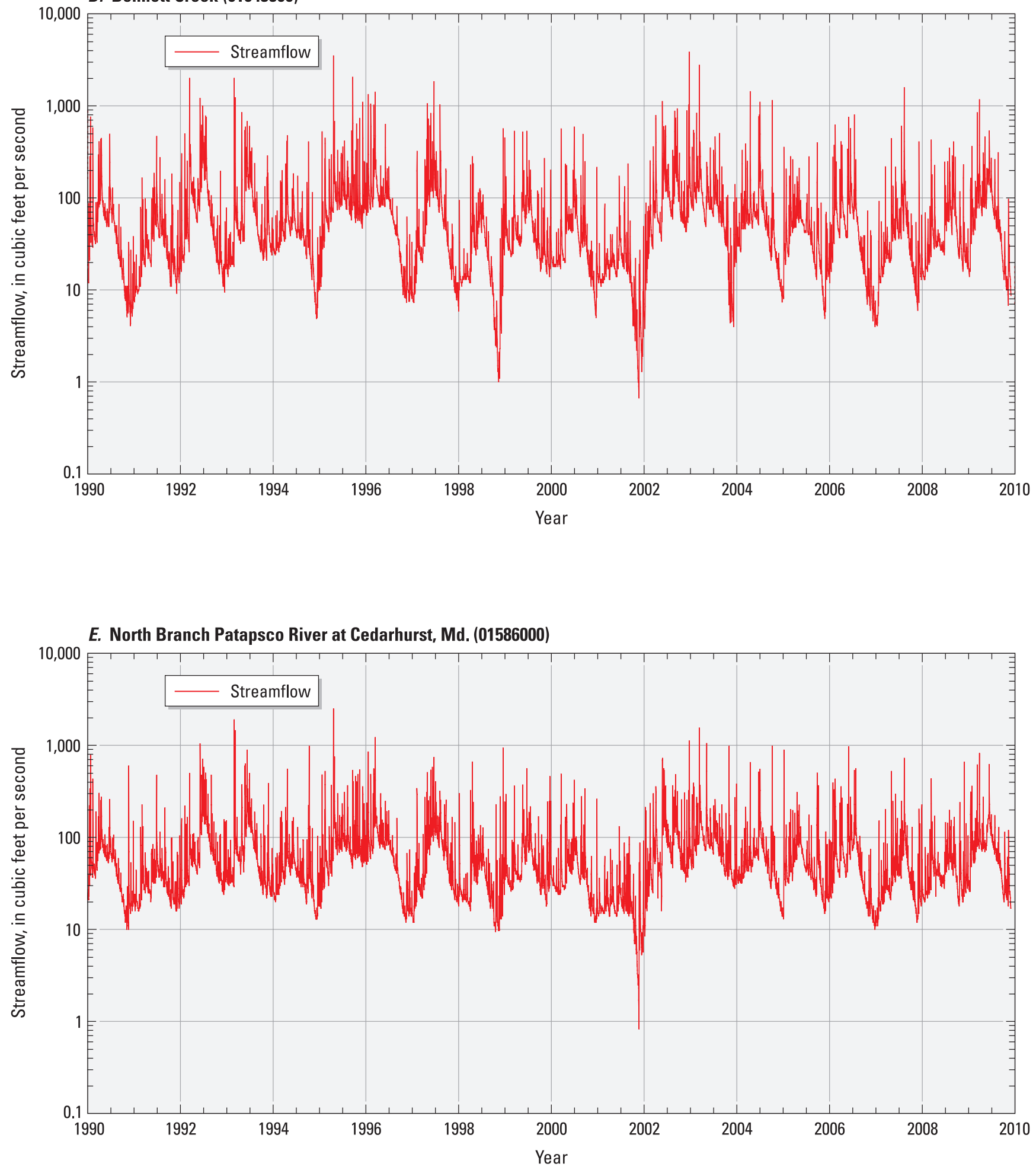

Figure 4. (A) central Maryland and hydrographs of groundwater levels for (B) water-table well BA Ea 18, Baltimore County, (C) water-table well FR Df 35, Frederick County, and streamflow for (D) Bennett Creek (01643500), and (E) North Branch Patapsco River at Cedarhurst, Md. (01586000).-Continued 


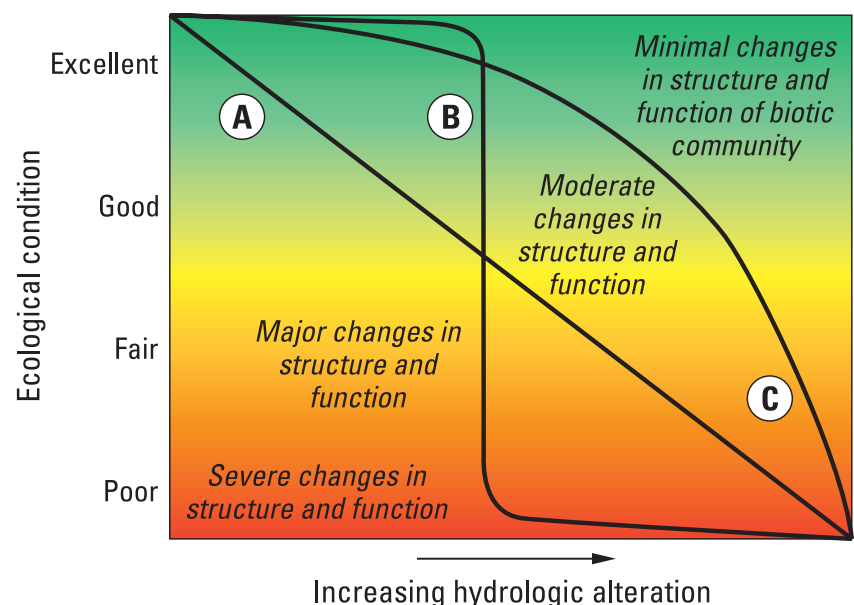

Figure 5. Example flow-ecology response curves showing relations between alterations in streamflow and ecological conditions for $(A)$ linear, $(B)$ critical thresholds, and $(C)$ nonlinear curves (modified from Davies and Jackson, 2006).

\section{Hydrogeologic Setting}

The fractured rock region of Maryland can be divided into four physiographic provinces: the Appalachian Plateau, Valley and Ridge, Blue Ridge, and Piedmont (Fenneman and Johnson, 1946). The eastern boundary of the Piedmont Province is the Fall Line (fig. 6A), named for the rapids and waterfalls that often occur at contact between the sedimentary deposits of the Coastal Plain and the crystalline bedrock of the Piedmont. Groundwater flow occurs primarily in the secondary porosity of the rocks (fractures, joints, and faults), with some groundwater flow in the intergranular space within sandstones. In areas underlain by carbonate rocks, fractures may become enlarged by the dissolution of rock by circulating groundwater. It is important not to associate aquifers with individual geologic units, because water-bearing properties can be affected by regional geologic structure as well as lithology.

The unconsolidated overburden, or regolith, covering bedrock has hydrologic properties distinct from the underlying rock and may be a significant factor in the recharge and storage of groundwater. The hydrologic properties of overburden depend on its origin. In much of the Piedmont Physiographic Province, saprolite has formed in place by prolonged weathering of crystalline bedrock. Saprolite thickness depends on its parent material and location relative to surface drainage (it is thinnest near large streams). Elsewhere in the fractured rock region, overburden consists of alluvium and colluvium, sediments that have been transported and deposited along streams and the base of hill slopes. These are particularly thick along the slopes of Catoctin Mountain and South Mountain (that lie on the east and west side of the Blue Ridge Physiographic Province, respectively), and the mountains just to the west of the Hagerstown Valley.

\section{Appalachian Plateau}

The Appalachian Plateau in Maryland covers all of Garrett County and the western edge of Allegany County. Bedrock consists mostly of sandstone, shale, and siltstone, but conglomerate, limestone, and coal are also present. Ridges mark where resistant layers are exposed. One of these ridges, Backbone Mountain-Big Savage Mountain, spans Garrett County and includes the highest point in Maryland 3,360 feet (ft). The drainage networks are deeply incised and controlled by geologic structure. In most areas, soils have formed from in situ weathering; some soils have also formed in alluvium (water-transported sediments) or colluvium (gravity-transported sediments).

Most groundwater movement occurs along fractures and bedding planes, although sandstones (particularly those of Pennsylvanian and Mississippian age) also possess intergranular permeability (Amsden and others, 1954). Groundwater flow takes place at local scales (generally under water-table conditions) and regional scales, under artesian conditions (Duigon and Smigaj, 1985). There are numerous areas where the land has been disturbed by surface or underground coal mining. Mine dewatering can have a substantial impact on groundwater levels near active mines, but water levels can also be affected by mineral exploration (Duigon and Smigaj, 1985 ) and post-mining activities. This area also overlies the Marcellus Shale, which is being developed for natural gas production (Soeder and Kappel, 2009). It is unclear what impacts the development of the Marcellus Shale will have on water resources within this region.

\section{Valley and Ridge}

The Valley and Ridge Province in Maryland covers Allegany and Washington Counties and the very southwestern edge of Frederick County. This province is characterized by alternating ridges and valleys. The predominant lithology is shale and limestone. The ridges are formed by sandstones, with lesser amounts of limestone and siltstone. Geologic structure is oriented primarily northeast-southwest and because of the variable resistance to erosion of sandstone and shale, is responsible for the parallel ridges and valleys.

The folded rocks of this section are well consolidated, with little primary porosity. Groundwater generally moves through fractures and bedding-plane separations, much like the Appalachian Plateau. The limestone rocks can have karstic conditions, namely, enlargement of fracture and bedding-plane voids by the solvent action of circulating groundwater, but karst development is limited because of the narrow extent of limestone formations in this region.

In the Hagerstown Valley, the Maryland part of the Great Valley, the outstanding characteristic is the development of karst, a collection of landforms and hydrologic characteristics that derive from the solubility of the carbonate bedrock. Karst development is more extensive in the Hagerstown Valley because of more substantive limestone deposits. 


\section{A. Physiographic provinces}

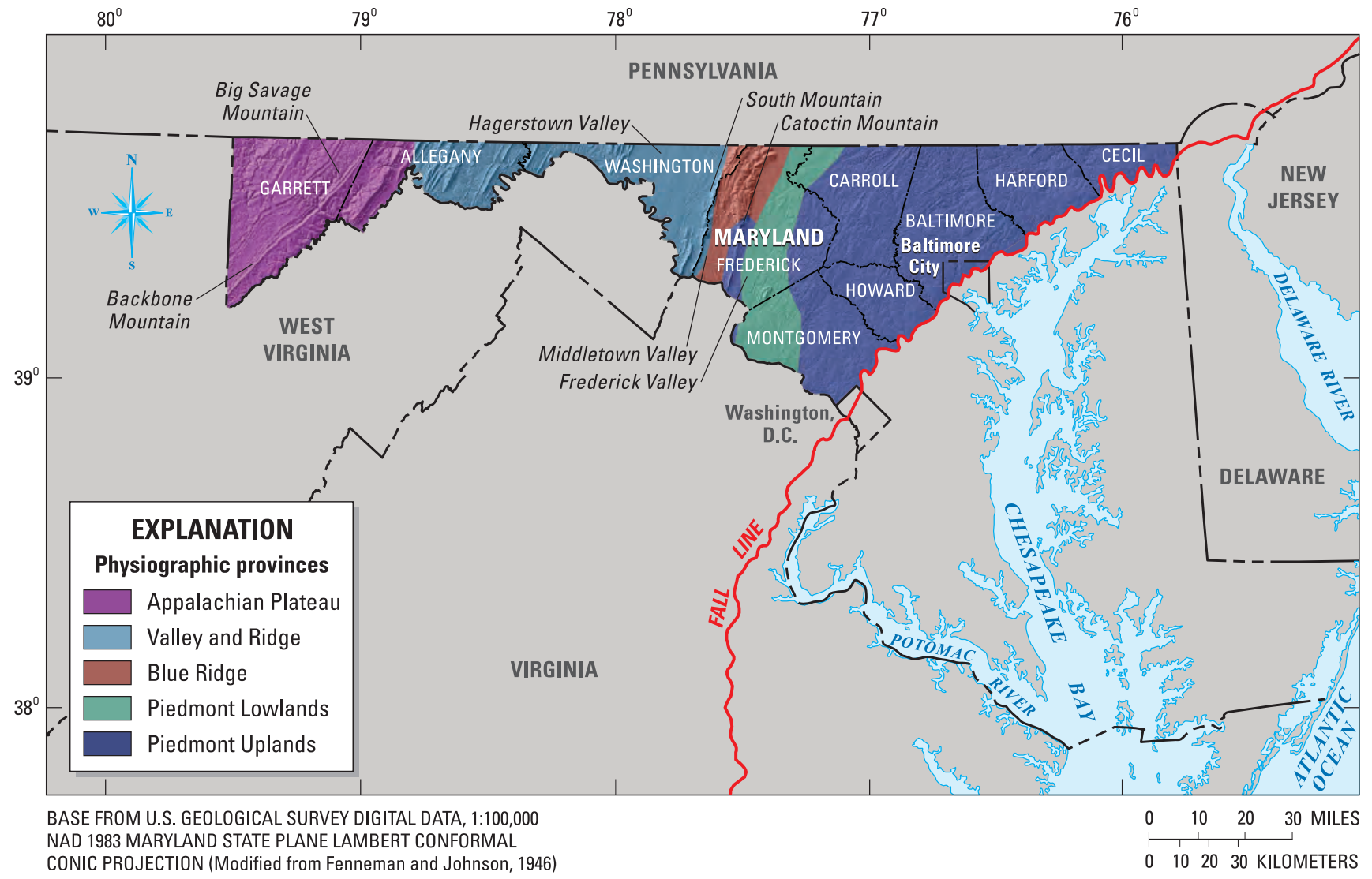

Figure 6. (A) physiographic provinces and conceptual groundwater-flow diagrams for $(B)$ carbonate rocks, $(C)$ coal-bearing rocks in the Appalachian Plateau, $(D)$ crystalline rocks in the Piedmont Uplands, and $(E)$ Mesozoic basin in the Piedmont Lowlands.

\section{Blue Ridge}

This province encompasses the area from South Mountain (adjacent to the Hagerstown Valley) to Catoctin Mountain. The core (Middletown Valley) is underlain mainly by gneiss, metabasalt, and metarhyolite; the mountains are underlain primarily by metasedimentary rocks. Metabasalt and metarhyolite also underlie the northern part of the province in Maryland where the mountains converge in Frederick County.

Bedrock permeability of the Blue Ridge rocks is secondary, whereas intergranular permeability of colluvium may be fairly high if clay content is low. The water table is typically below the base of the colluvium in many areas, however, Fauth (1977) and Dine and others (1985) reported water levels within colluvium deposits in several observation wells.

\section{Piedmont}

The Piedmont has three distinct geologic areas - carbonate, siliciclastic, and igneous and metamorphic crystalline rocks. The Piedmont carbonate area consists of limestone and dolomite in the Frederick Valley. To the east, limestone and dolomite have been metamorphosed into marble in various subdivisions of the crystalline region. Areas underlain by these rocks tend to be flat-bottomed valleys caused by the solubility of the rock, and their broadness depends on the width of the carbonate rocks near land surface. These rocks possess low primary permeability, but in many places, fractures have been enlarged by dissolution of wall rock, locally providing very high permeability.

To the north and south of the Frederick Valley are the Piedmont sedimentary deposits, commonly referred to as the Mesozoic Lowlands or Piedmont Lowlands (fig. 6A), underlain by shale, sandstone, and conglomerate rocks. These rocks are mostly well compacted and cemented; therefore, groundwater circulation in them depends on the presence of interconnected fractures. Joints tend to be more closely spaced in the sandstone and conglomerate, making the rock more transmissive (Nutter, 1975). Significant water-bearing zones can be found at depths greater than $500 \mathrm{ft}$ (unlike in the crystalline rocks of the Piedmont Uplands) (Nutter, 1975). 


\section{B. Carbonate rocks}

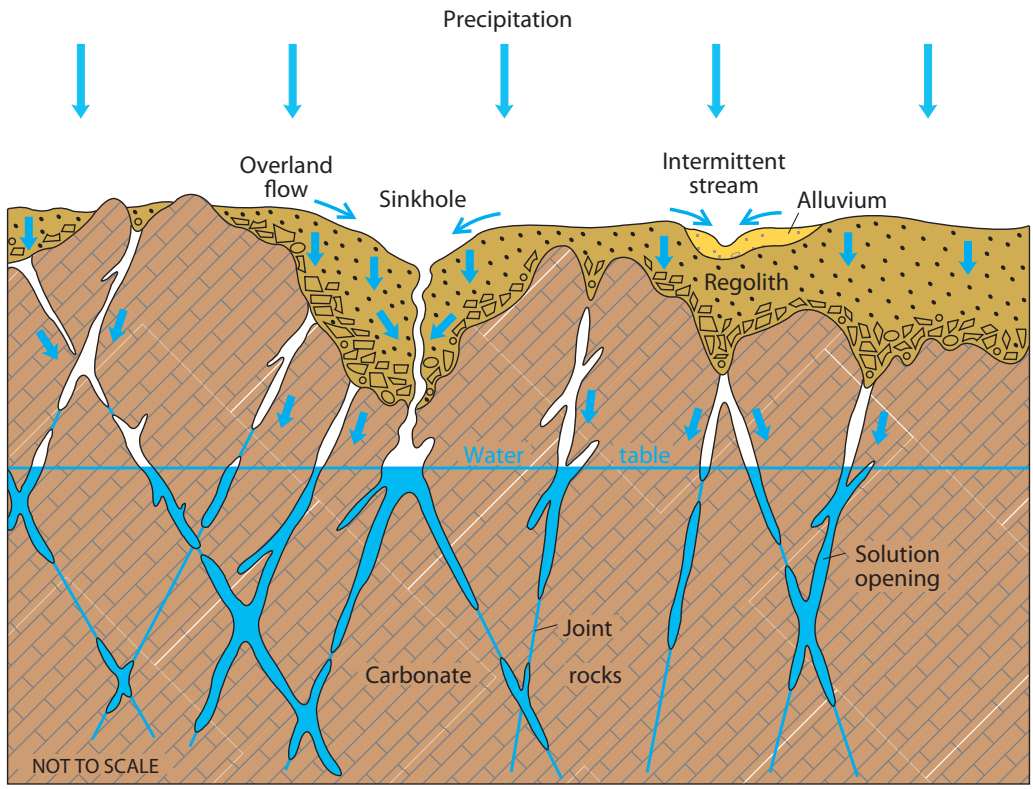

Modified from Nutter, 1973.

\section{Coal-bearing rocks in the Appalachian Plateau}

\section{EXPLANATION}

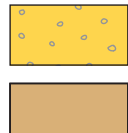

Colluvium and alluvium

Weathered bedrock

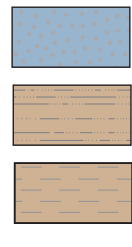

Sandstone

Siltstone

Shale

Coal seam

$\rightarrow \quad$ Direction of groundwater movement

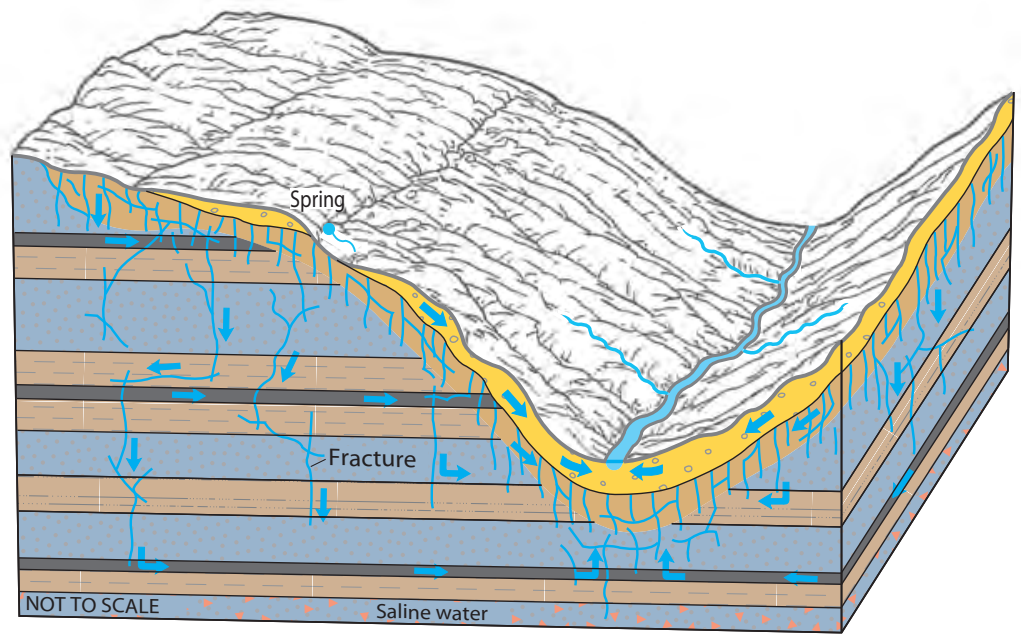

Modified from Harlow and LeCain, 1993.

Figure 6. (A) physiographic provinces and conceptual groundwater-flow diagrams for $(B)$ carbonate rocks, $(C)$ coalbearing rocks in the Appalachian Plateau, (D) crystalline rocks in the Piedmont Uplands, and (E) Mesozoic basin in the Piedmont Lowlands.-Continued 


\section{Crystalline rocks in the Piedmont Uplands}

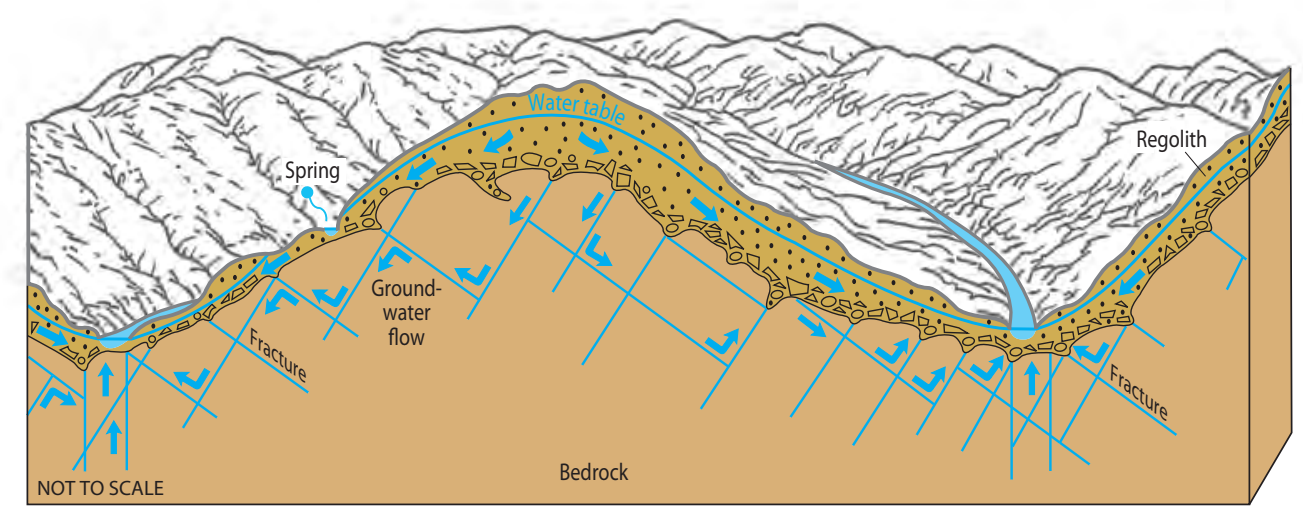

Modified from Heath, 1980.

\section{E. Mesozoic basin in the Piedmont Lowlands}

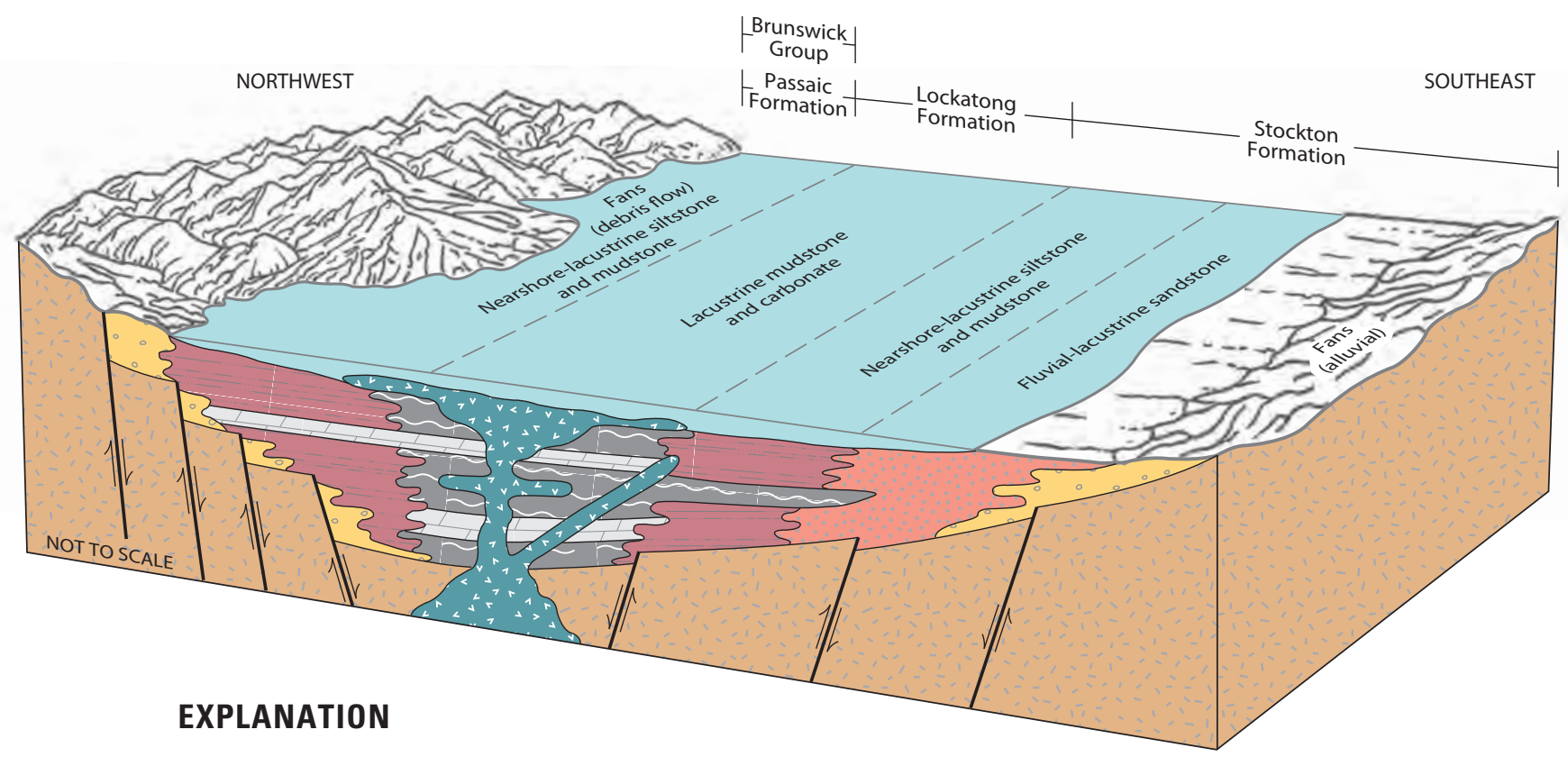

Conglomerate

Modified from Turner-Peterson and Smoot, 1985.

Sandstone

Siltstone

Mudstone

Dolomite

Diabase and basalt

Crystalline rocks

Fault-Arrows show relative direction of movement

Figure 6. (A) physiographic provinces and conceptual groundwater-flow diagrams for $(B)$ carbonate rocks, $(C)$ coal-bearing rocks in the Appalachian Plateau, $(D)$ crystalline rocks in the Piedmont Uplands, and (E) Mesozoic basin in the Piedmont Lowlands. - Continued 
The igneous and metamorphic Piedmont area consists of crystalline rocks, encompassing most of the physiographic province. The province includes terranes accreted during plate tectonic activity, evinced by the type and degree of metamorphism, and displacement of rock. The crystalline rocks are generally covered by saprolite. Permeability tends to be somewhat higher in the upper part of the modern soils that have developed in the top of the saprolite, where clay has been eluviated, and lower at depth, where the clay has been transported. The highest permeabilities are typically found at the saprolite/fresh-rock interface or transition zone (Harned and Daniel, 1992). Saprolite thickness and properties vary according to rock type and topographic position. Within the competent bedrock, groundwater flow is dominated by secondary porosity of fractures and joints.

\section{Previous Studies}

From 1952 to 1962, several water resource bulletins were published for the Baltimore area (Bennett and Meyer, 1952), Garrett County (Amsden and others, 1954), Howard and Montgomery Counties (Dingman and others, 1954), Baltimore and Harford Counties (Dingman and others, 1956), Carroll and Frederick Counties (Meyer and Beall, 1958), and Allegany and Washington Counties (Slaughter and Darling, 1962). These reports were typically divided into sections on groundwater and surface water. Groundwater sections contained a well inventory and groundwater-quality data for the assessment area. The surface-water sections presented monthly discharge at selected streamgages. From 1969 to 1975, several studies were carried out on groundwater resources in distinct physiographic provinces (fig. 6A): the Piedmont (Nutter and Otton, 1969), the Triassic Rocks of Maryland (Nutter, 1975) and the Frederick and Hagerstown Valleys (Nutter, 1973). From 1975 to 1999 , reports were published that describe a statewide groundwater-quality network (Bolton, 1996), Piedmont springs (Otton and Hilleary, 1985), Garrett County (Duigon and Smigaj, 1985; Hiortdahl, 1988; Nutter and others, 1980), Carroll County (Hilleary and Weigle, 1981), Westminster, Md. (Duigon, 1992), Frederick County (Dine and others, 1985; Duigon and Dine, 1987), Harford County (Nutter, 1977), Cecil County (Otton and others, 1988), Howard County (Dine and others, 1995), and Washington County (Duigon and others, 1989; Duigon and Dine, 1991).

These studies provided a significant amount of basic data, including: well-construction information, driller's estimated yields, as well as descriptions of the groundwater flow systems and groundwater quality. Collectively, the reports have provided the scientific understanding that is still widely used to describe groundwater-flow systems; however, several decades of additional data are available that could improve our understanding of these systems. MDE and various permittees have conducted numerous studies as part of the exploration and development of public water supplies. Other work on the impact of water withdrawals on aquatic biota has recently been initiated. Long-term monitoring of water levels associated with water withdrawals highlights the potential for impacts on other users as well as the sustainability of various uses. A substantial amount of unpublished data were collected during the earlier studies that may be useful for identifying the best yielding areas for the development of new water supplies without causing unreasonable impacts, including decreased streamflows and well yields from withdrawals. Beyond the State boundary, regional studies (Swain and others, 2004; Trapp and Horn, 1997) described conceptual models of groundwater flow, water-use summaries, and broad groundwater-quality issues in the Mid-Atlantic region. Recent studies in Virginia (Nelms and Moberg, 2010, 2011) described the complex fractured rock aquifer systems in Clarke and Warren Counties. In addition, groundwater systems in the North Carolina Piedmont have been studied (Chapman and others, 2005; Daniel, 1989; Daniel and others, 1997).

Officials from scientific and resource management agencies in Maryland such as MDE and MDDNR recognize that for this assessment to be comprehensive, the assessment area will need to extend to adjacent watersheds in Pennsylvania, Virginia, and West Virginia. The utilization of information from previous studies and readily available data from adjacent states is necessary as Maryland contains many watersheds with headwaters in surrounding states.

\section{Description of Science Goals and Assessment Activities}

The comprehensive assessment of groundwater and surface-water supply in the fractured rock region of Maryland (referred to hereafter as the Maryland Fractured Rock Study), was developed on the basis of five "Science Goals." In this section, each goal is discussed, the need for new work is explained, and the assessment activities necessary to achieve the goal are outlined. The science goals are:

1. Develop tools for the improved management and investigation of groundwater and surface-water resources.

2. Characterize factors affecting reliable yields of individual groundwater and surface-water supplies.

3. Investigate impacts to other water withdrawal users caused by surface-water and groundwater withdrawals.

4. Assess the role of streamflow and water withdrawals on the ecological integrity of Maryland's streams.

5. Improve understanding of the distribution of waterquality conditions in fractured rock aquifers.

The information needs for this assessment are related to the reliability of groundwater resources and the in-stream flows needed to sustain healthy aquatic habitats in Maryland streams. Water chemistry and water quality will be an 
important component of this assessment as they relate to the availability of potable groundwater supplies, stream health, and the impacts of human activities such as coal and gas extractions. The effects of global climate change on streamflow and groundwater supplies in Maryland are unknown. This assessment will include analysis of climatic impacts on surface-water and groundwater supplies.

The Maryland Fractured Rock Study is very broad in scope. Scientists from different backgrounds will need to work closely with resource managers. A multidisciplinary approach is required to address the issues described in this assessment. New analytical methods will be developed and a variety of modeling and statistical approaches will be applied.

\section{Science Goal 1: Develop Tools for the Improved Management and Investigation of Groundwater and Surface-Water Resources}

The Water Supply Program at MDE is tasked with ensuring the equitable allocation of water among users without causing unreasonable impacts on the environment. An example of an unreasonable impact from a withdrawal at a nearby high-volume production well would be the loss of a domestic water supply due to water-level declines. An unreasonable impact from a stream withdrawal would be the depletion of critical habitat of a high-value surface-water resource during critical flow periods (summer low-flow conditions). Maryland water resource managers need new and more efficient tools to apply the best available scientific knowledge to the fractured rock region. Currently (2012), water-appropriation applications are evaluated by professional staff using analyses and data from published reports and other agency resources. These reports are often in a hard-copy format and contain detailed information on well locations, stream impacts from withdrawals, streamflow statistics, aquifer test results, and geologic descriptions.

\section{Need for New Work}

To efficiently evaluate water-allocation requests, information on water use, groundwater levels, and the location of monitoring sites is needed in a timely fashion. These data currently reside in multiple State and Federal databases and need to be compiled for use in both management and research applications. Water resource managers have expressed the need for a computerized system that will allow them to access all available data and summarize, graphically display, and visualize the data and interpretive information for specific areas of interest. Water Supply Program staff need Geographic Information Systems (GISs) containing comprehensive groundwater, surface-water, and water-use information that will allow users full access to all pertinent aquifer and stream data.

Existing water resources databases must be migrated, new data must be incorporated as they are collected, and historical data must be digitized for inclusion in a computerized system. Systematically organizing all relevant data will improve the efficiency of water allocations. A GIS framework for water resources (Maidment, 2002) describes a data model for organizing data in a GIS for surface-water resources and more recently, Strassberg and others (2011) presented a data model specifically for groundwater data. Both data models will be used to compile Maryland's water resource data from multiple sources including: the USGS National Water Information System (NWIS), the MDE Water Supply Program's Public Drinking Water Information System (PDWIS), and the MDDNR Maryland Biological Stream Survey (MBSS) into a GIS system for the fractured rock region.

Reliable streamflow data are crucial for permit evaluators of surface-water and groundwater allocations in the fractured rock region of Maryland. Streamflow targets, such as the 7-day, 10-year low flow (7Q10) are used by MDE when considering a new water allocation permit. StreamStats is a Web-based GIS application that was created by the USGS, in cooperation with Environmental Systems Research Institute, Inc. to provide users with access to an assortment of analytical tools that are useful for water-resources planning and management (Ries and others, 2008). Many statistics derived from the StreamStats application, including the 7Q10 flow, are used by the MDE Water Supply Program for water allocation permits using the water-balance method. However, StreamStats has only been implemented near the Interstate 95 corridor. An expansion of its geographic extent could provide the State with another tool to assist in water allocation permitting.

GIS will allow integration of diverse datasets and facilitate spatial analyses that will be required to meet the needs of water resource managers. Many of the interpretive products from this assessment will be integrated into a GIS work platform.

\section{Objectives and Proposed Assessment Activities}

Objective A-Develop a database to assist permit managers, scientists, and planners with accessing and evaluating data related to water supply.

- Develop a Fractured Rock Aquifer Information System (FR-AIS) that will provide users with access to pertinent hydrologic data in a GIS software environment.

- Integrate water-use data into the FR-AIS.

Objective B-Develop statistical and analytical tools to assist water managers.

- Expand the StreamStats application to all of Maryland.

- Develop statistical and analytical models to assist MDE in allocating permits. 


\section{Science Goal 2: Characterize Factors Affecting Reliable Yields of Individual Groundwater and Surface-Water Supplies}

The sustained yields of wells in fractured rock aquifers can decline significantly in response to dry climatic conditions (Hammond, 2004). During the regional drought of 1998-2002, which was one of the three worst droughts on record (in addition to the droughts of 1930-32 and 1962-68), the major surface-water suppliers in the Baltimore-Washington metropolitan area were able to meet customer demand; however, Prettyboy Reservoir in Baltimore County was significantly depleted. In contrast, many of the small to medium-sized towns (populations less than 50,000) in the fractured rock region instituted voluntary or mandatory water-use restrictions as a result of declining well yields and reservoir storage. Most of the water-supply yields were substantially less than those estimated by hydrologists or engineers who conducted initial aquifer tests of the water-supply wells or evaluations of reservoir capacities. In the case of groundwater exploration programs, some were more successful than others, likely due to differing hydrologic factors in the areas where drilling occurred. Finally, there were reports of many failures of individual domestic wells of private homeowners, which required replacement wells to be drilled.

\section{Need for New Work}

In order to prevent well failure in the future and better estimate drought yields, new methods of characterization and analysis in fractured rock systems need to be applied and refined. Commonly, multidisciplinary approaches are being used to evaluate regional groundwater systems. The combined use of aquifer tests, geophysical logs, groundwater-level observations, and statistical and numerical models, can provide a greater understanding of a groundwater system than one method alone (Shapiro and others, 2007).

Aquifer tests that run for 24 hours or longer have been a requirement for permit evaluation by MDE for several decades. MDE has compiled several hundred aquifer tests in the fractured rock region of Maryland. The methods used by MDE for evaluating aquifer tests and estimating yields of wells in fractured rock aquifers were developed prior to the start of the 1998-2002 drought, beginning in the early 1990s. In a study performed by MDE staff (Hammond, 2004), production data were collected from supply wells and springs during 1998-2002 and compared to original yield estimates from aquifer tests. The study revealed that original estimates using commonly applied analytical techniques consistently overestimated the yield of wells during drought conditions. A subset of aquifer tests was re-evaluated using a variety of analytical methods, including derivative analysis, and yield results more closely matched actual yields determined from production data. This highlights the importance of collecting operational data over a period of years, and the need to re-evaluate existing aquifer tests from supply wells in the fractured rock region of Maryland.

Although there have been numerous studies attempting to define the sustainable yield of aquifers, there have been very few studies that address how to estimate the reliable yield of individual water-supply wells in fractured rock aquifers. In two studies conducted in similar hydrogeologic settings to Maryland - a carbonate aquifer in Pennsylvania (Parizek and Siddiqui, 1970) and a crystalline rock Piedmont aquifer in North Carolina (Daniel, 1989) - predicted yields significantly overestimated actual yields. In addition, a study in crystalline rocks in South Africa (van Tonder and others, 2001) provided well yield predictions; however, a post audit to confirm study predictions was not performed.

To better predict reliable yields, factors affecting well yields need to be determined for different hydrogeologic regions in Maryland. Many studies concerning factors affecting yields of wells in fractured rock aquifers depend largely on data collected from residential wells (Dine and others, 1995; Mabee, 1999). The studies usually examine similar factors (such as well depth, diameter, casing depth, rock type, topographic position, and driller's estimated yield) and often only provide qualitative insights. However, advances in computational ability allow for more robust spatial and statistical analysis. Multivariate analyses have been conducted to estimate well yield probabilities (Moore and others, 2002), and geostatistical methods have been used to relate well yields to structural controls in New Hampshire and Virginia (Drew and others, 1999; Drew and others, 2003; Drew and others, 2004). Further development of statistical and spatial analysis methods could lead to quantitative relations between well yields and hydrogeologic factors. For this comprehensive assessment, relevant data will be compiled and stored in the FR-AIS and greater emphasis will be placed on the detailed review of public supply wells.

An important factor in understanding reliable yields of wells in fractured rock is the identification of the most productive water-bearing zones in a borehole. Unlike wells constructed in unconsolidated sediments with fully penetrating well screens, most wells in fractured rock are cased to competent rock with open borehole for tens to hundreds of feet below. Water enters the well from fractures or discrete zones within the geologic formation penetrated by the borehole. The depth of the fractures or water-bearing zones in the well bore can determine the reliable yield for that well. Shallow waterbearing zones may be more susceptible to decreased yields during drought than deeper water-bearing zones. Geophysical logging methods have been used to determine major flow zones in fractured rock wells (Paillet and Ollila, 1995; Williams and others, 2002). In North Carolina and Georgia, geophysical logging studies in the Piedmont and Blue Ridge Provinces were conducted (Chapman and Huffman, 2011; McSwain and others, 2009; Williams and others, 2005). To date, only a small number of supply wells have had geophysical logs collected using these methods in Maryland. 
Surface-water systems supply most of the demand in the fractured rock region of Maryland and need to be considered in any assessment of water availability. Reliable yields of surface-water supplies have been determined for most of the major reservoirs in central and western Maryland, using flow mass analysis techniques that rely on estimates of inflow and reservoir geometry (Beard, 1966; Riggs and Hardison, 1973). However, the aggregate and cumulative impacts of withdrawals from reservoirs and simple intakes generally have not been considered when making previous water allocation decisions. In addition, most permits for withdrawals from existing reservoirs and many stream withdrawals were issued more than 25 years ago, when the most common flow-by condition was based on the 7Q10 low-flow value, whereas subsequent standards include higher and more variable environmental flows.

\section{Objectives and Proposed Assessment Activities}

Objective $A$-Evaluate factors that affect yields of public water supply wells.

- Collect and compile aquifer test, production, geophysi$\mathrm{cal}$, and other appropriate geologic data for public supply wells.

- Re-analyze existing aquifer test data and evaluate factors that impact well yields of public water supplies both individually and spatially.

- Evaluate numerical and analytical methods to estimate drought yields of individual wells in each hydrogeologic setting.

Objective $B$-Evaluate factors that impact yields of domestic wells.

- Delineate areas with similar hydrogeologic characteristics that may affect well yield.

- Identify factors including rock type, degree of fracturing, correlation with surface geologic structural controls, and other factors and their relative influence on domestic well yields.

Objective C-Improve methods for estimating yields of surface-water reservoirs and simple intakes.

- Estimate reliable yields of surface-water reservoirs and simple intakes.

\section{Science Goal 3: Investigate Impacts on Other Water Withdrawal Users Caused by Surface- Water and Groundwater Withdrawals}

Determining the area of influence from withdrawal wells completed in fractured rock aquifers is difficult because the hydrogeologic characteristics of fractured rocks are complex (Barton and others, 2003). In Maryland, aquifer tests of wells in fractured rock are used to evaluate the impacts of groundwater withdrawals on nearby water supplies. MDE requires monitoring programs during aquifer tests; however, observation wells are not always available to account for anisotropic and heterogeneous water-level responses that commonly occur during aquifer tests in fractured rock aquifers. This can lead to substantial uncertainty in the assessment of potential impacts on other users. To avoid impacts to streams, MDE assigns minimum flow conditions to surface-water permits and has recently considered requiring biological assessments, on a case-by-case basis, to determine impacts on aquatic habitat caused by groundwater and surface-water withdrawals.

\section{Need for New Work}

Data from the monitoring programs required by MDE indicate that there can be substantial errors when estimating drawdown in nearby wells caused by groundwater withdrawals. To date, most of the errors involved drawdown that was underestimated, primarily because of the unreliability of data taken from open-borehole observation wells. In several cases, there was no measured drawdown in nearby observation wells when pumping a proposed production well; however, followup studies or post-audits indicated that there was severe interference between the wells.

The Water Supply Program uses relatively simple analytical techniques to define an effective well radius (equal to one-quarter fracture length determined by iteratively adjusting the storage coefficient and radius terms in the Theis equation until calculated and observed drawdown in the pumping well match) instead of the actual well radius to calculate drawdown in pumping wells. The heterogeneity of an aquifer is estimated by assigning higher storage and transmissivity values to the weathered zone than to the bedrock part of the aquifer. The calculated fracture length and estimated hydraulic parameters are then used to model drawdown in monitoring wells to predict impacts on nearby wells belonging to other users. Although this improves the estimates of drawdown made with commonly used methods that were derived for porous media systems (Theis, 1935; Cooper and Jacob, 1946), there are still substantial errors (approximately 50-100 percent) associated with the technique. These methods were developed in lieu of numerical models, since reliable numerical analyses often require more data than is commonly available at most sites. A number of studies, including those by van Tonder and others (2001), Rushton and Chan (1976) and Tiedeman and Hsieh (2001), have utilized numerical analyses to define groundwater flow in fractured rock aquifers. Over the past two decades, MDE has collected aquifer test and groundwater-level-monitoring data from several dozen sites throughout the study area that can be used to improve both numerical and analytical methods for evaluating potential impacts to other groundwater users.

Reasonable estimates of interference between wells can be made based on a good deal of experience and knowledge of local hydrogeology. Even the best projections can have 
substantial errors, but the most reliable method for demonstrating the degree of interference between wells has been consistent monitoring that has included periods of drought.

In Pennsylvania, where hydrogeologic regions are similar to Maryland, a multidisciplinary approach (aquifer test analysis, geophysical logging, water-level observations, and groundwater-flow modeling) was developed to delineate the contributing area to wells in crystalline rocks (Barton and others, 2000) and siliciclastic rocks (Barton and others, 2003). In Massachusetts, geologic mapping, borehole geophysics, aquifer tests, and numerical models were used to delineate the contributing areas to public supply wells completed in fractured rock (Lyford and others, 2003). In Connecticut, groundwater-flow models were used to determine sourcewater areas for bedrock wells at different topographic positions with varying surficial aquifer thickness (Starn and Stone, 2005). MDE requires that an inventory be completed to identify nearby water supplies and determine which ones should be monitored during aquifer tests. The radial distances from a proposed production well within which inventories have to be completed have been based on case studies conducted by MDE over the past 20 years: $1,500 \mathrm{ft}$ for crystalline rocks; $2,000 \mathrm{ft}$ for carbonate rocks; and 3,000 ft for siliciclastic rocks (though changes in groundwater levels have occurred at more than 5,000 ft). Using other methods in addition to aquifer tests and water-level observations can help to determine whether the existing radial distances are sufficient to identify potential impacts on other water users.

For surface waters, low-flow releases or flow-bys are used to protect downstream users from impacts caused by upstream surface-water withdrawals. For low-flow analyses, a USGS continuous-record streamgage applicable to the project site is selected, on the basis of similarity of lithology and climate, period of record, and lack of impacts on the streamgage by upstream regulation. Although the best professional judgment can lead to acceptable streamgage selection for this analysis, additional statistical approaches would improve the selection of the best-correlated available streamgage record. A flow duration curve is then constructed from the selected streamgage data. Seasonal flow-bys are then calculated from the monthly 85-percent exceedance values. This approach is referred to as the Maryland Method. For permits issued prior to adoption of the present criteria and agricultural uses, the $7 \mathrm{Q} 10$ value was commonly used to determine flow-bys.

To determine if currently used methods are sufficient to avoid adverse impacts on other water users, case studies using a multidisciplinary approach including numerical models are needed. As previously noted, the data required for numerical models are often not available, but with the development of several Research Watersheds, sufficient data will be available to calibrate numerical models and test adverse impact scenarios. The Research Watersheds will include groundwater observation wells and streamgages; aquifer tests and geophysical logging will be performed to characterize each setting. These Research Watersheds will integrate geologic, hydrologic, and biological data to examine processes and impacts.
Models with information from these watersheds can be scaled to perform case studies and used to evaluate drought scenarios and potential associated impacts. Analytical methods to determine the distance of potential impacts from groundwater withdrawals, the depth of groundwater-flow systems, and the water balance method currently used by MDE can all be assessed with Research Watershed models. Supplemental work, such as groundwater sampling for environmental tracers, can improve our ability to model these complex systems (Cook and Herczeg, 2000; Cook and others, 2005; Cook and others, 1996). Groundwater-flow models alone may not be sufficient to characterize Research Watersheds and evaluate current water balance methods. Groundwater systems in fractured rock settings interact more readily with streams and climate than the confined aquifers in Coastal Plain settings. Recent developments in coupled surface- and groundwater modeling such as GSFLOW (Markstrom and others, 2008) allow for more realistic representations of the hydrologic system than groundwater-flow models alone. In addition to streamflow and groundwater levels, additional data including air temperature, precipitation, estimated solar radiation, and land-surface characteristics are needed. Contributions of groundwater to streamflow, and potential impacts that groundwater withdrawals may have on streamflow can also be investigated with numerical models of selected watersheds.

\section{Objectives and Proposed Assessment Activities}

Objective A-Identify and assess the influence of factors that affect the impact of withdrawals on other water users.

- Select Research Watersheds.

- Install field monitoring wells and streamgages.

- Collect and compile data needed to build surfacewater/groundwater models.

- Develop coupled surface-water/groundwater models for selected watersheds.

- Evaluate the relation of groundwater withdrawals to potential impacts on streamflow.

- Analyze environmental tracers from samples in Research Watersheds to characterize groundwater-flow systems.

- Utilize coupled surface-water/groundwater models to investigate the impact on water resources from projected climate change impacts, such as more frequent or more severe droughts, and more frequent extreme storms.

Objective B-Evaluate methods for determining impacts of withdrawals on other water users.

- Use numerical and analytical models to test effective radii for aquifer tests in different hydrogeologic settings. 
- Evaluate current water balance methods using coupled surface-water/groundwater models in selected watersheds.

\section{Science Goal 4: Assess the Role of Streamflow and Water Withdrawals on the Ecological Integrity of Maryland's Streams}

It is fundamental to the sustainability of water resources in the fractured rock region of Maryland to gain an improved understanding of the potential impacts of water withdrawals on the ecology of streams (Wolman, 2008). MDE's Water Supply Program makes water resource permitting decisions with the goal of ensuring that no unreasonable impacts are made on the State's resources or the ecological health of nontidal streams. Streams in poor ecological condition are listed on Maryland's list of impaired waters and require a restoration plan. According to Maryland's anti-degradation regulation, high quality Tier II waters (designated based on ecological condition) are afforded special protection. Regulations also afford special protection to natural trout waters (designated as Use Class III), recreational trout waters (Use-IV), public water supplies (Use I-P, III-P, and IV-P), and streams with rare, threatened, or endangered State species. Although biological inventories and streamflow records have been collected in Maryland for many years, the relations between them are not well understood. Obtaining a better scientific understanding of the relation between water withdrawals and the ecological health of streams will aid MDE in achieving its objectives of protecting aquatic ecosystems.

In 2011, MDE and MANTA developed seven management questions which will guide hydroecological integrity assessment activities:

1. Which Maryland stream species (including rare, threatened, endangered, game, invasive, and migratory species) and ecosystems are most/least sensitive to flow alterations? Are there specific biological indicators of water withdrawal?

2. Which aspects of flow regimes have the most/least influence on stream species and ecosystems? How do alterations in flow affect species and ecosystems? Can the specific mechanisms responsible for flow alterations be determined and described?

3. Which components of flow-ecology relations are most/ least affected by surface (intake and impoundment) and groundwater withdrawals?

4. What relations between surface-water and groundwater withdrawals and stream ecological integrity can be established?

5. For past and future water-uses, how have/might surface-water and groundwater withdrawals impact individual species and ecosystems (including possible scenarios such as: flooding, drought, increasing population, cumulative impacts, climate change, confounding factors, and so forth)?

6. What spatial and seasonal aspects of flow need to be maintained for specific streams, including under drought conditions to ensure the protection of stream species and ecosystems?

7. Is additional research/monitoring needed?

\section{Need for New Work}

In order to address these management questions, an investigation to assess the relations among water withdrawals, flow alteration, and aquatic biota in Maryland is needed. Water quality and quantity are vitally important to aquatic biota (such as stream-dependent fish, benthic macroinvertebrates, freshwater mussels, crayfish, amphibians, and reptiles). Flow is strongly related to many critical physiochemical components of streams, such as water temperature, dissolved oxygen, channel morphology, and habitat. Many recent studies indicate that streamflow is a "master variable," limiting the distribution, abundance, and diversity of many aquatic plant and animal species, and thus the overall ecological integrity of stream ecosystems (Poff and others, 1997; Kennen and Ayers, 2002; Olden and Poff, 2003; Richter and others, 2003; Carlisle and others, 2010). The alteration of flowing waterways has had dire consequences on aquatic biota that have been well documented (Allan and Flecker, 1993). To avoid adverse impacts, the range of natural flows found in Maryland's streams must be identified and the influence these natural flows have on aquatic biota must be understood (fig. 5). With an adequate understanding of natural flow regimes, the potential influences of altered flow regimes that could result from water withdrawals can subsequently be investigated. Detailed streamflow data are available from over 100 streamgages in Maryland and can be estimated for ungaged sites. In addition, extensive biological and physiochemical stream information has been collected from more than 3,700 sites since 1995.

The Hydroecological Integrity Assessment Process (HIP) (Henriksen and others, 2006; Kennen and others, 2007) and the Ecological Limits of Hydrologic Alteration (ELOHA) (Arthington and others, 2006; Aspe and others, 2008; The Nature Conservancy, 2008) are two relatively new procedures that correlate large amounts of hydrological and ecological data as a means of defining stream types within a region and determining flows needed to sustain riverine ecosystems. Both processes are based largely on the methods described by (Olden and Poff, 2003).

To estimate a broader set of streamflow statistics, such as those required for HIP and ELOHA, estimates of daily time-series of streamflow are needed. The USGS has developed regression equations for estimating various streamflow statistics for every state in the Nation, and methods for developing such equations are well documented in USGS 
publications, such as Ries and Dillow (2006). Analyses to develop these conventional equations require computation of the streamflow statistic of interest and measurement of various physical and climatic characteristics of the drainage basins for a group of streamgages within a region with flows that are minimally impacted by human activities. A regression analysis to determine the best equation for use in estimating the flow statistic for ungaged sites in the region must then be performed. Statistical methods for estimating daily time series at ungaged sites are have been effective in southern New England (Fennessey, 1994; Waldron and Archfield, 2006). These methods have been refined, modified, and applied to additional sites in New England and Pennsylvania (Archfield and others, 2010; Archfield, 2009; Archfield and Vogel, 2010; Marla Stuckey, U.S. Geological Survey, oral commun., 2012).

MDE's Water Supply Program has compiled a database that tracks water withdrawal permit information from over 600 (more than 200 surface-water and 400 groundwater) fractured rock water withdrawal locations. This database includes the monthly permitted and reported amounts of water, and each permit can be linked to a specific watershed. These data provide valuable information for determining where water withdrawal impacts on aquatic biota are most likely to occur.

Through the MBSS, MANTA has compiled an extensive database of stream biological data for nontidal streams (Heimbach and others, 1999). Examples of the biological data collected by the MBSS since 1995 include fish, benthic macroinvertebrates, freshwater mussels, crayfishes, amphibians, reptiles, physical habitat, water quality, riparian characteristics, and catchment land use. Fish and Benthic Macroinvertebrate Indices of Biotic Integrity (FIBI and BIBI) were developed for use in Maryland streams using MBSS data (Southerland and others, 2007). MANTA also annually monitors 27 high quality streams ("Sentinel" sites) across the State (fig. 7). Data collected at these sites are used to assess natural variability in stream conditions. MBSS data have been widely used to investigate ecological correlations with water quality, physical habitat, and land use (Hilderbrand and others, 2010; Morgan and Cushman, 2005; Morgan and others, 2007; Pinder and Morgan, 1995; Stranko and others, 2008; Utz and others, 2009) and are used by MDE and MDDNR to establish regulations that restore and protect streams (such as impaired waters, high quality waters, designated use, and endangered species). However, this comprehensive assessment represents the first time these data will be used to investigate potential impacts on biology from water withdrawal or other flow alterations. Sites determined to have the highest probability of impact from water withdrawal will be monitored annually for biological condition. Data from these sites will be compared with annually collected data from MBSS Sentinel Sites to determine if temporal changes in stream conditions at sites with substantial withdrawal significantly differ from conditions at reference sites.

Estimates of streamflow statistics that describe the magnitude, frequency, duration, timing, and rate of change of streamflow at currently ungaged streams including MBSS sites, as well as water-use information, would allow a statistical analysis that could define relations among biotic integrity, streamflow, water use, water quality, and watershed physical characteristics. Recently developed methods to estimate daily flow at ungaged streams (Archfield and others, 2010) will be implemented for streams in Maryland. Before estimates of daily flow can be made, prior work identifying index streamgages (Armstrong and others, 2008; Falcone and others, 2010) must first be completed. Other streamflow modeling efforts with some common geographic area, including those by the Interstate Commission on the Potomac River Basin (ICPRB) and The Nature Conservancy for the Middle Potomac Watershed will be assessed for their applicability for use as a permitting tool for MDE. Results from the overall hydroecological assessment will be used to implement scientifically sound methods for planning and evaluating water withdrawal applications, consider potential effects of withdrawals to streamflow and ecological integrity, and avoid potential water-quality and biological degradation.

\section{Objectives and Proposed Assessment Activities}

Objective A-Evaluate flow regimes.

- Determine existing index streamgages.

- Refine and implement statistical methods for estimating daily streamflow at ungaged streams.

- Derive required streamflow statistics from estimated daily time series of streamflow at ungaged sites.

Objective B-Assess the relation of changes in flow regimes to stream ecological health.

- Perform an extensive literature review to assess previously documented results and trends.

- Evaluate the health and streamflow needs of aquatic species and their habitats using information from the MBSS, the MDE Water Supply Program, and USGS streamgage network data.

- Design and implement field studies to investigate critical and potentially complex factors that impact aquatic biota (such as water withdrawal, thermal regimes, natural flow regimes, water quality, and land-use alteration) in Research Watersheds.

Objective C-Develop guidelines/recommendations and (or) tools for water managers.

- Determine whether existing models or other watershed assessment models can be adapted for use as MDE planning and permitting tools.

- Evaluate current MDE flow-by methodologies; develop post-decision permit monitoring protocols.

- Update the FR-AIS with applicable data resulting from this assessment.

- Publish reports with assessment results. 


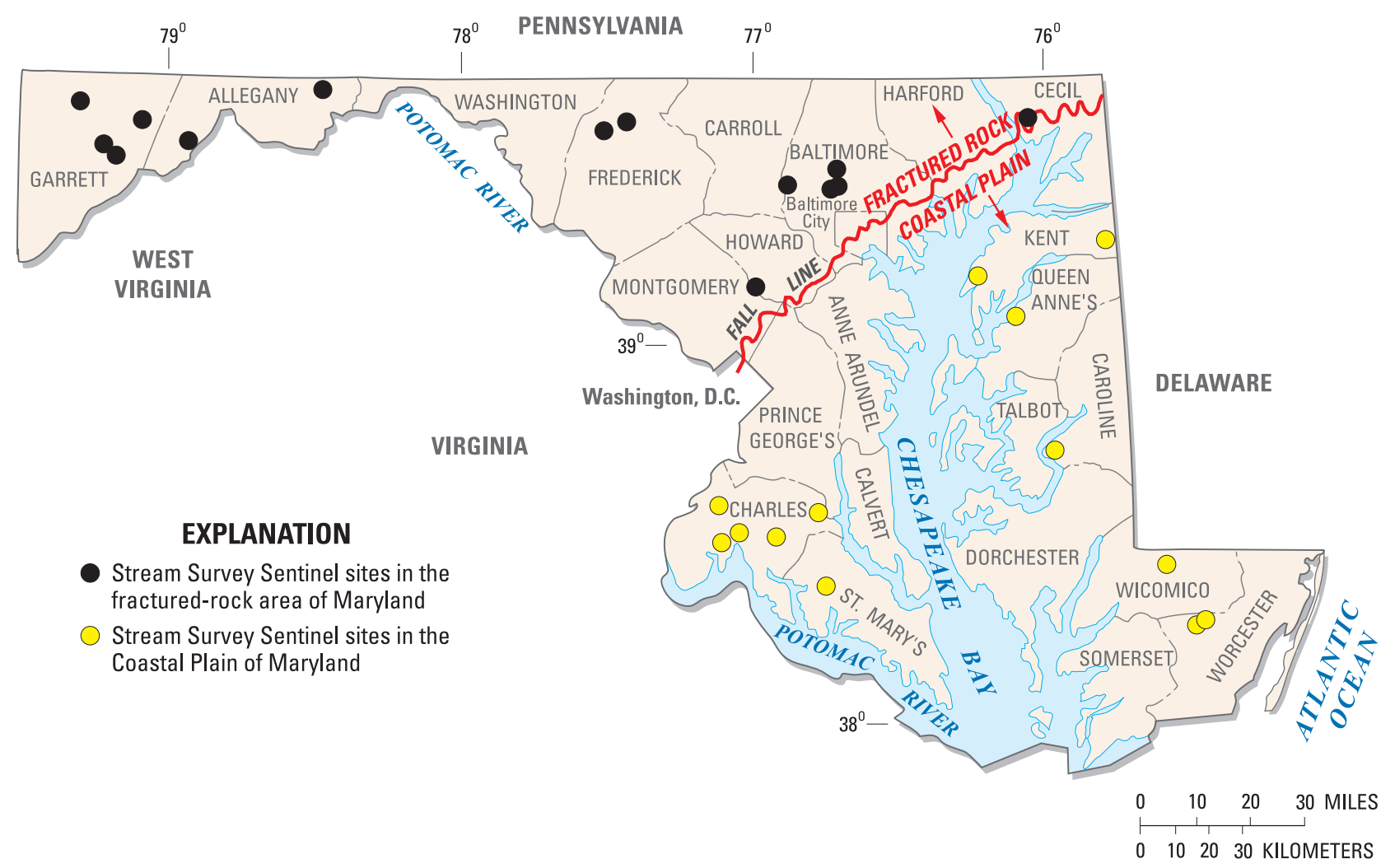

Figure 7. Location of the Maryland Biological Stream Survey Sentinel sites.

\section{Science Goal 5: Improve Understanding of the Distribution of Water-Quality Conditions in Fractured Rock Aquifers}

In the fractured rock region of Maryland, untreated groundwater from individual domestic wells is a significant source of potable water for much of the population (table 2). Water-quality constituents of concern for domestic groundwater supply vary by rock type and land use. Naturally occurring constituents such as radionuclides are more commonly found at higher concentrations in the felsic igneous and metamorphic rocks of the Piedmont and Blue Ridge Provinces. Shale in both the Valley and Ridge and Mesozoic basin with felsic minerals in the source rocks also tends to have higher concentrations of radionuclides including radon, radium, and uranium (Johnson and others, 2011) whereas sandstone and carbonate rocks tend to have lower concentrations of radionuclides. Radium and other radionuclides have been detected in isolated locations of the fractured rock region of Maryland, but their occurrence and distribution are not well understood.
Arsenic has been detected in wells drilled in the siliciclastic rocks of Garrett County (David Bolton, Maryland Geological Survey, written commun., 2011), where domestic wells are the major source of drinking water. Nitrate and fecal-indicator bacteria are also groundwater-quality concerns. Groundwater samples from both the Potomac and Lower Susquehanna River Basins, which include wells in the fractured rock region of Maryland in the Valley and Ridge, Blue Ridge, and Piedmont Physiographic Provinces, have contained nitrate concentrations near or above 10 milligrams per liter (mg/L), the U.S. Environmental Protection Agency (USEPA) Maximum Contaminant Level (MCL), with the highest mean nitrate concentrations in carbonate aquifers of the Piedmont aquifer system (Lindsey and others, 2006). Because of the potential for rapid infiltration of runoff into the groundwater system, carbonate aquifers are susceptible to other surface contaminants including fecal-indicator bacteria. In the Valley and Ridge aquifers, the highest colony count of fecal-indicator bacteria tend to be in samples from wells in agricultural areas overlying carbonate rock aquifers (Johnson and others, 2011). 
Table 2. Percent of population served by domestic groundwater wells for each county in the fractured-rock region of Maryland, 2005.

\begin{tabular}{|lc|}
\hline County & $\begin{array}{c}\text { Percent of population served by } \\
\text { domestic groundwater wells' }\end{array}$ \\
\hline Garrett & 72 \\
\hline Cecil & 59 \\
\hline Carroll & 51 \\
\hline Frederick & 38 \\
\hline Washington & 38 \\
\hline Harford & 31 \\
\hline Howard & 18 \\
\hline Allegany & 14 \\
\hline Baltimore & 8 \\
\hline Montgomery & 2 \\
\hline
\end{tabular}

${ }^{1}$ Susan Hutson, U.S. Geological Survey, written commun., 2012

\section{Need for New Work}

Groundwater-quality data have been collected across the fractured rock region of Maryland by many studies at various scales. As part of the National Water-Quality Assessment (NAWQA) Program, the USGS has collected and analyzed water-quality data across the fractured rock region in the Potomac River Basin (Ator and Denis, 1997; Blomquist and others, 1996; Ferrari and Ator, 1995; Gerhart and Brakebill, 1998) and the Lower Susquehanna River Basin (Lindsey and others, 1998). MGS established a statewide groundwater-quality network beginning in 1989 (Bolton, 1996). Hydrogeologic investigations of the carbonate valleys and the Triassic rocks of Maryland (Nutter, 1973, 1975) reported groundwater-quality results but focused more on groundwater availability than water quality. County-scale studies of water resources (Dine and others, 1995; Dine and others, 1985) and water quality (Bolton, 1998) have compiled a broad suite of water-quality data, including major ions, nutrients, and metals, and County health departments also require that groundwater-quality samples be collected for selected constituents. Additionally, several unpublished studies of specific groundwater-quality issues have been conducted by MGS (David Bolton, Maryland Geological Survey, written commun., 2011).

Substantial amounts of groundwater-quality data from fractured rock aquifers in Maryland have been collected and analyzed. Methods for sample collection, laboratory analysis, and data storage vary and are dependent on the goals of the individual study in which they were obtained. With existing data from multiple studies of various scales, improved understanding of groundwater-quality patterns can likely be accomplished by summarizing and categorizing existing data to characterize the distribution of groundwater-quality patterns across the fractured rock region of Maryland that may affect water-use decisions.

In addition to the interpretation of existing data, there may be a need to enhance the existing groundwater-quality network. New data collection for constituents such as methane that are associated with hydrocarbon extractions may be warranted in shallow aquifers that overlie coal deposits and the Marcellus Shale Formation. Additional sampling may be required to determine the age of groundwater to improve the conceptual frameworks of groundwater chemistry for selected aquifers in the Research Watershed studies. Groundwater in some hydrogeologic settings has not been adequately evaluated for many constituents that have USEPA Primary Drinking-Water Standards.

Individual groundwater-quality studies involving extensive collection and analysis of groundwater samples may be beyond the scope of this assessment. However, compiling available groundwater-quality information from local and national sources will assist in future investigations of groundwater quality in the fractured rock region of Maryland.

\section{Objectives and Proposed Assessment Activities}

Objective A-Make groundwater-quality data more accessible to researchers and resource managers.

- Compile available groundwater-quality information from multiple sources into the FR-AIS.

- Prepare selected groundwater-quality data analysis products for integration into management tools (GIS) as needed.

Objective $B$-Evaluate and improve the adequacy of waterquality data.

- Enhance water-quality networks in selected locations to track changes in water quality with respect to USEPA Primary or Secondary MCLs.

- Evaluate existing groundwater-quality data to identify areas that have not been fully evaluated with respect to USEPA Primary Drinking-Water Standards and other criteria.

- Establish hydrologic and water-quality monitoring sites to fill in data gaps.

- Establish monitoring sites to use as a baseline to determine potential impacts of future activity, such as gas extraction from the Marcellus Shale. 


\section{Assessment Implementation}

The science goals for this comprehensive assessment will be addressed throughout the long-term, multi-year study. Whereas many tasks throughout the assessment can be performed simultaneously because of the assessment's broad nature, some tasks provide the foundation or tools for subsequent tasks and others are simply precursory. In order to take full advantage of available resources, the development of an overall work plan is crucial in identifying the dependency of individual tasks and to lay out the critical path of the project.

The assessment will begin by building partnerships with Federal, State, and local agencies, and assembling a multidisciplinary team of scientists and regulators to perform the comprehensive assessment. Information gaps will be identified and detailed work plans will be developed to address those gaps and address each science goal. The initial development of the FR-AIS is one of the principal efforts required to begin the assessment. Data compilation from various sources will be incorporated into the FR-AIS. Along with FR-AIS development, hydrogeologic regions for the fractured rock region will be classified, low-flow frequency statistics for streams will be updated, the StreamStats web application will be expanded to encompass the entire State, geophysical logging data from production wells will be collected, and Research Watersheds will be identified.

Once these activities are complete, significant effort will be placed on activities including the analysis of potential factors affecting groundwater availability in different hydrogeological regions, the refinement of methods used to estimate the daily streamflow time series from which relevant streamflow statistics can be derived, monitoring Research Watersheds, and studying the potential relation between hydrology and aquatic habitats.

Compared to the Maryland Coastal Plain, the hydrogeological characteristics of the fractured rock region are more heterogeneous, and this makes simulation of the groundwaterflow system a more challenging task. With adequate hydrologic data at appropriate scales, groundwater models (or coupled surface-water and groundwater models) of Research Watersheds will allow the evaluation of conceptual models (Weathered Zone, Transition Zone, Fractured Bedrock), assumptions about recharge, base flow and groundwater interactions with streams, as well as hypotheses concerning the potential impacts due to climate change.

Throughout the assessment, the science team comprised of personnel from MDE, MGS, MANTA, and USGS, will continue to seek opportunities to apply various scientific findings by developing new tools, improving existing methodologies, developing models and simulations, and providing education and outreach. The FR-AIS will house data such as aquifer-test data, well-construction information, geophysical logs, and many other spatial data as they become available. Data from the FR-AIS will allow the development of tools to interpret and display results for desktop and Web-based applications.

\section{Products and Benefits}

Implementation of the Maryland Fractured Rock Study is designed to provide an enhanced understanding of the fractured rock aquifer systems and the response of stream ecosystems to water withdrawals in Maryland. Additionally, the assessment aims to provide information related to the integrated nature of climate, ecosystems, and water resources in the region. The broad scope of the assessment necessitates expertise from multiple disciplines allowing for a unique opportunity to develop an interdisciplinary team of water resource managers, ecologists, geologists, and hydrologists.

A number of important products and tools resulting from this assessment will benefit water resource managers, decision makers, planners, policy makers, stakeholders, and scientists including:

- A GIS-based Aquifer Information System specific to the fractured rock regions of Maryland FR-AIS to assist MDE Water Supply Program decision making regarding future water allocations.

- An improved understanding of factors affecting reliable yields in individual water supply wells.

- Estimates of mean daily flow at ungaged streams.

- An improved understanding of the distribution of water quality, particularly with regard to USEPA drinkingwater standards.

- An improved understanding of the impacts of withdrawals on other water withdrawal users.

- A better understanding of stream ecosystem thresholds.

- A better understanding of hydrologic response to climate change.

- Improved communication between Federal, State and local water resource managers.

\section{Interagency Coordination and Outreach}

The diverse nature of the assessment will require the participation of scientists and managers with different technical backgrounds and presents an excellent opportunity to advance the current knowledge of Maryland's water resources and ecology in an interdisciplinary fashion. This will in turn lead to improved management of water resources north and west of the Fall Line in Maryland. To take advantage of this opportunity, a significant effort will be placed on interagency coordination. Coordination between MDE, MGS, MANTA, and the USGS has taken place throughout the development of this Science Plan and will continue as work plans are developed. Work teams have been established for developing new tools, planning and performing the hydroecological analysis, and 
assessing reliable well yields. Continued coordination is necessary to establish the details of future assessment activities.

To reach a larger audience, Web sites will be developed and made publicly accessible. Other planned outreach endeavors include presentations and posters at local and regional technical meetings to disseminate interim findings, describe the assessment plans, and solicit feedback from stakeholders. It is anticipated that a number of scientific reports and journal articles will be published by coordinating agencies. Anticipated reports will be written on topics including (1) the hydrogeologic regions west of the Fall Line, (2) the estimation of daily streamflow at ungaged sites, (3) factors affecting the reliable yield of water supply wells, and (4) the relations between streamflow and stream ecology.

\section{Concluding Remarks}

The fractured rock region in Maryland includes a significant variety of topographic, hydrogeologic and climatic settings that impact the quantity of available water, the distribution of streamflow, water quality, the abundance and health of aquatic organisms, and the safety of water for human consumption. Human activities affect the need for water, alter the hydrologic cycle, and impact water quality, which in turn affects the abundance and health of aquatic organisms and the safety of water for human consumption. Activities conducted during this comprehensive assessment will be designed to acquire and analyze sufficient data to better understand these relations in order to develop improved predictive tools to help water resource managers, water suppliers, policy makers, scientists, planners and others address the following questions:

- What are the flow characteristics at locations without streamgages?

- What are the groundwater recharge rates at any location?

- How do groundwater withdrawals impact streamflows?

- What are the best methods for estimating the reliable yields of water supplies?

- What are favorable locations to explore for additional groundwater supplies that minimize impacts, ensure sustainability, and increase the potential for highyielding wells?

- What are the streamflow characteristics that need to be preserved to ensure a healthy aquatic ecosystem?

- What methods can best predict if a proposed use will negatively impact other water withdrawal users?

- What are the cumulative impacts of multiple groundwater and surface-water withdrawals on streamflow in a particular watershed?
- In what areas are domestic wells at greater risk to naturally occurring contaminants?

- In what areas are certain activities more likely to negatively impact water quality?

- What are the impacts that may occur due to the implementation of revised reservoir release rules, flow-by requirements, or water balance criteria?

A better understanding of these issues will help the Maryland water resource community address both anticipated and unexpected current and future water resource challenges.

\section{Acknowledgments}

The authors wish to thank John Grace, Lyn Poorman, and John Smith for their contributions to this report with a special thanks to Stacy Boyles and Jason Zhao, fractured rock study project managers (Maryland Department of the Environment). Thanks are also extended to David Bolton (Maryland Geological Survey), and James Gerhart (formerly of the U.S. Geological Survey) for suggestions on an early draft of this report. Additional thanks are extended to Matthew Pajerowski, Kernell Ries, and Susan Hutson (U.S. Geological Survey) for providing background and supporting information, and finally to Melinda Chapman and Leslie DeSimone (U.S. Geological Survey) for thorough peer review that substantially improved the report.

\section{References Cited}

Allan, J.D., and Flecker, A.S., 1993, Biodiversity conservation in running waters: BioScience, v. 43, no. 1, p. 32-43.

Amsden, T.W., Singewald, J.T., Overbeck, R.M., and Martin, R.O.R., 1954, Geology and water resources of Garrett County: Maryland Geological Survey Bulletin 13, 349 p., 11 pls.

Archfield, S.A., 2009, Estimation of continuous daily streamflow at ungaged locations in Southern New England: Medford, Massachusetts, Tufts University, Ph.D. dissertation, [variously paged].

Archfield, S.A., and Vogel, R.M., 2010, Map correlation method: Selection of a reference streamgage to estimate daily streamflow at ungaged catchments: Water Resources Research, v. 46, W10513, 15 p., doi:10.1029/2009WR008481. 
Archfield, S.A., Vogel, R.M., Steeves, P.A., Brandt, S.L., Weiskel, P.K., and Garabedian, S.P., 2010, The Massachusetts Sustainable-Yield Estimator: A decisionsupport tool to assess water availability at ungaged stream locations in Massachusetts: U.S. Geological Survey Scientific Investigations Report 2009-5227, 41 p. plus CD-ROM (also available online at http://pubs.usgs.gov/ sir/2009/5227/).

Armstrong, D.S., Parker, G.W., and Richards, T.A., 2008, Characteristics and classification of least altered streamflows in Massachusetts: U.S. Geological Survey Scientific Investigations Report 2007-5291, 113 p. plus CD-ROM (also available online at http://pubs.usgs.gov/ sir/2007/5291/).

Arthington, A.H., Bunn, S.E., Poff, N.L., and Naiman, R.J., 2006, The challenge of providing environmental flow rules to sustain river ecosystems: Ecological Applications, v. 16, no. 4 , p. $1,311-1,318$.

Aspe, C., DePhillip, M., Zimmerman, J., and Smith, M.P., 2008, Developing instream flow criteria to support ecologically sustainable water resource planning and management: Final report to the Pennsylvania Instream Flow Technical Advisory Committee: Harrisburg, Pennsylvania, The Nature Conservancy, $195 \mathrm{p}$.

Ator, S.W., and Denis, J.M., 1997, Relation of nitrogen and phosphorus in ground water to land use in four subunits of the Potomac River Basin: U.S. Geological Survey WaterResources Investigations Report 96-4268, 26 p.

Barton, G.J., Risser, D.W., Galeone, D.G., and Conger, R.W., 2000, Case study for delineating a contributing area to a water-supply well in a fractured crystalline-bedrock aquifer, Stewartstown, Pennsylvania: U.S. Geological Survey Water-Resources Investigations Report 99-4047, 38 p.

Barton, G.J., Risser, D.W., Galeone, D.G., and Goode, D.J., 2003, Case study for delineating a contributing area to a well in a fractured siliciclastic-bedrock aquifer near Lansdale, Pennsylvania: U.S. Geological Survey WaterResources Investigations Report 02-4271, 46 p.

Bates, B.C., Kundzewicz, Z.W., Wu, S., and Palutikof, J.P., eds., 2008, Climate change and water: Technical Paper VI of the Intergovernmental Panel on Climate Change (IPCC): Geneva, IPCC Secretariat, $210 \mathrm{p}$.

Beard, L.R., 1966, Methods for determination of safe yield and compensation water from storage reservoirs, TP-3: Davis, California, U.S. Army Corps of Engineers, 24 p.

Bennett, R.R., and Meyer, Rex, 1952, Geology and groundwater resources of the Baltimore area: Maryland Department of Geology, Mines and Water Resources Bulletin 4, 573 p.
Blomquist, J.D., Fisher, G.T., Denis, J.M., Brakebill, J.W., and Werkheiser, W.H., 1996, Water-quality assessment of the Potomac River Basin: Basin description and analysis of available nutrient data, 1970-90: U.S. Geological Survey Water-Resources Investigations Report 95-4221, 88 p.

Boicourt K., and Z.P. Johnson eds., 2010, Comprehensive strategy for reducing Maryland's vulnerability to climate change, Phase II: Building societal, economic, and ecological resilience, Report of the Maryland Commission on Climate Change Adaptation and Response and Scientific and Technical Working Groups: Cambridge, Maryland, University of Maryland Center for Environmental Science, and Annapolis, Maryland, Maryland Department of Natural

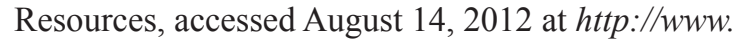
dnr.state.md.us/climatechange/climatechange_phase2 adaptation_strategy.pdf.

Bolton, D.W., 1996, Network description and initial waterquality data from a statewide ground-water-quality network in Maryland: Maryland Geological Survey Report of Investigations No. 60, 167 p.

Bolton, D.W., 1998, Ground-water quality in the Piedmont region of Baltimore County, Maryland: Maryland Geological Survey Report of Investigations No. 66, 191 p.

Bolton, D.W., Gerhart, J.M., and Kasraei, Saeid, 2009, Sustainability of water resources in the fractured-rock area of Maryland: U.S. Geological Survey Fact Sheet 20093009, 2 p. (also available online at http://pubs.usgs.gov/ $\left.f_{S} / 2009 / 3009 /\right)$.

Carlisle, D.M., Falcone, James, Wolock, D.M., Meador, M.R., and Norris, R.H., 2010, Predicting the natural flow regime: models for assessing hydrological alteration in streams: River Research and Applications, v. 26, no. 2, p. 118-136, DOI:10.1002/rra.1247.

Chapman, M.J., Bolich, R.E., and Huffman, B.A., 2005, Hydrogeologic setting, ground-water flow, and groundwater quality at the Lake Wheeler Road research station, 2001-03, North Carolina Piedmont and Mountains Resource Evaluation Program: U.S. Geological Survey Scientific Investigations Report 2005-5166, 85 p.

Chapman, M.J., and Huffman, B.A., 2011, Geophysical logging data from the Mills Gap Road area near Asheville, North Carolina: U.S. Geological Survey Data Series 538, 49 p. plus attachment, available online only at $h t t p: / / p u b s$. usgs.gov/ds/538/.

Cook, P.G., and Herczeg, A.L., 2000, Environmental tracers in subsurface hydrology: Boston, Kluwer, 529 p.

Cook, P.G., Love, A.J., Robinson, N.I., and Simmons, C.T., 2005, Groundwater ages in fractured rock aquifers: Journal of Hydrology, v. 308, nos. 1-4, p. 284-301, http://dx.doi. org/10.1016/j.jhydrol.2004.11.005. 
Cook, P.G., Solomon, D.K., Sanford, W.E., Busenberg, Eurybiades, Plummer, L.N., and Poreda, R.J., 1996, Inferring shallow groundwater flow in saprolite and fractured rock using environmental tracers: Water Resources Research, v. 32, no. 6, p. 1,501-1,509.

Cooper, H.H., and Jacob, C.E., 1946, A generalized graphical method for evaluating formation constants and summarizing well field history: Transactions of the American Geophysical Union, v. 27, p. 526-534.

Daniel, C.C., 1989, Statistical analysis relating well yield to construction practices and siting of wells in the Piedmont and Blue Ridge Provinces of North Carolina: U.S. Geological Survey Water Supply Paper 2341-A, 27 p. (also available online at http://pubs.usgs.gov/wsp/2341a/report. $p d f)$.

Daniel, C.C., Smith, D.G., and Eimers, J.L., 1997, Hydrogeology and simulation of ground-water flow in the thick regolith-fractured crystalline rock aquifer system of Indian Creek Basin, North Carolina: U.S. Geological Survey Water Supply Paper 2341-C, 137 p. (also available online at http://pubs.usgs.gov/wsp/2341c/report.pdf).

Davies, S.P., and Jackson, S.K., 2006, The biological condition gradient: a descriptive model for interpreting change in aquatic ecosystems: Ecological Applications, v. 16, no. 4, p. 1,251-1,266.

Dine, J.R., Adamski, J.C., and Duigon, M.T., 1995, Water resources of Howard County, Maryland: Maryland Geological Survey Bulletin 38, 128 p.

Dine, J.R., Adamski, J.C., and Tompkins, M.D., 1992, Hydrologic data for Howard County, Maryland: Maryland Geological Survey Basic Data Report 19, 240 p.

Dine, J.R., Tompkins, M.D., and Duigon, M.T., 1985, Ground-water and surface-water data for Frederick County, Maryland: Maryland Geological Survey Basic Data Report No. 15,240 p.

Dingman, R.J., Ferguson, H.F., and Martin, R.O.R., 1956, Water resources of Baltimore and Harford Counties: Maryland Geological Survey Bulletin 17, 233 p., 11 pls.

Dingman, R.J., Meyer, G., and Martin, R.O.R., 1954, The water resources of Howard and Montgomery Counties: Maryland Geological Survey Bulletin 14, 260 p., 8 pls.

Drew, L., Karlinger, M., Armstrong, T., and Moore, R., 1999, Relations between igneous and metamorphic rock fracture patterns and groundwater yield from the variography of water-well yields_-Pinardville Quadrangle, New Hampshire: Natural Resources Research, v. 8, no. 2, p. 137-152.
Drew, L.J., Karlinger, M.R., Schuenemeyer, J.H., and Armstrong, T.R., 2003, Hydrogeologic significance of the association between well-yield variography and bedrock geologic structures, Pinardville Quadrangle, New Hampshire: Natural Resources Research, v. 12, no. 1, p. 79-91.

Drew, L.J., Southworth, S., Sutphin, D.M., Rubis, G.A., Schuenemeyer, J.H., and Burton, W.C., 2004, Validation of the relation between structural patterns in fractured bedrock and structural information interpreted from 2D-Variogram maps of water-well yields in Loudoun County, Virginia: Natural Resources Research, v. 13, no. 4, p. 255-264.

Duigon, M.T., 1992, Effects of development and novel construction techniques on yield of a water well drilled in crystalline rock, Westminster, Maryland: Maryland Geological Survey Report of Investigations No. 56, 53 p., 1 pl.

Duigon, M.T., and Dine, J.R., 1987, Water resources of Frederick County, Maryland: Maryland Geological Survey Bulletin 33, 106 p.

Duigon, M.T., and Dine, J.R., 1991, Water resources of Washington County, Maryland: Maryland Geological Survey Bulletin 36, 109 p.

Duigon, M.T., Dine, J.R., and Tompkins, M.D., 1989, Groundwater and surface-water data for Washington County, Maryland: Maryland Geological Survey Basic Data Report No. 18,273 p.

Duigon, M.T., and Smigaj, M.J., 1985, First report on the hydrologic effects of underground coal mining in southern Garrett County, Maryland: Maryland Geological Survey Report of Investigations No. 41, 99 p.

Falcone, J.A., Carlisle, D.M., Wolock, D.M., and Meador, M.R., 2010, GAGES: A stream gage database for evaluating natural and altered flow conditions in the conterminous United States: Ecology, v. 91, no. 2, p. 621, DOI: 10.1890/09-0889.

Fauth, J.L., 1977, Geologic map of the Catoctin Furnace and Blue Ridge Summit quadrangles, Maryland: Maryland Geological Survey Quadrangle Geologic Map, 1 sheet, scale $1: 24,000$.

Fenneman, N.M., and Johnson, D.W., 1946, Physical divisions of the United States: U.S. Geological Survey, 1 sheet, scale $1: 7,000,000$.

Fennessey, N.M., 1994, A hydro-climatological model of daily streamflow for the northeast United States: Medford, Massachusetts, Tufts University, Ph.D. dissertation, [variously paged]. 
Ferrari, M.J., and Ator, S.W., 1995, Nitrate in ground water in the Great Valley carbonate subunit of the Potomac River Basin: U.S. Geological Survey Water-Resources Investigations Report 95-4099, 6 p.

Gerhart, J.M., and Brakebill, J.W., 1996, Design and implementation of a sampling strategy for a water-quality assessment in the Potomac River Basin: U.S. Geological Survey Water-Resources Investigations Report 96-4034, 31 p.

Hammond, P.A., 2004, Well yields observed during two drought years compared with estimated yields in fracturedrock aquifers, case studies [abs]: 2004 Maryland StateCounty Ground Water Symposium, Maryland Department of the Environment, Septermber 29, 2004.

Harlow, G.E., Jr., and LeCain, G.D., 1993, Hydraulic characteristics of, and ground-water flow in, coal-bearing rocks of southwestern Virginia: U.S. Geological Survey WaterSupply Paper 2388, 36 p.

Harned, D.A., and Daniel, C.C., III, 1992, The transition zone between bedrock and regolith: conduit for contamination? in Proceedings of Groundwater in the Piedmont-A conference on groundwater in the Piedmont of the Eastern United States: Clemson, South Carolina, Clemson University, p. 336-348.

Heath, R.C., 1980, Basic elements of ground-water hydrology with references to conditions in North Carolina: U.S. Geological Survey Water-Resources Investigations OpenFile Report 80-44, 86 p.

Heimbach, D.G., Seibel, J.C., Wilson, H.T., and Kazyak, P.F., 1999, A multi-year lattice sampling design for Marylandwide fish abundance estimation: Journal of Agricultural, Biological, and Environmental Statistics, v. 4, no. 4, p. 443-455.

Henriksen, J.A., Heasley, John, Kennen, J.G., and Nieswand, Steven, 2006, Users' manual for the Hydroecological Integrity Assessment Process software (including the New Jersey Assessment Tools): U.S. Geological Survey OpenFile Report 2006-1093, 72 p., accessed February 27, 2012 at http://www.fort.usgs.gov/products/publications/pub_ abstract.asp? PubID $=21598$.

Hilderbrand, R.H., Utz, R.M., Stranko, S.A., and Raesly, R.L., 2010, Applying thresholds to forecast potential biodiversity loss from human development: Journal of the North American Benthological Society, v. 29, no. 3, p. 1,009-1,016.

Hilleary, J.T., and Weigle, J.M., 1981, Carroll County groundwater information: Well records, spring records, and chemical-quality data: Maryland Geological Survey Basic Data Report No. 12, 251 p.
Hiortdahl, S.N., 1988, Hydrologic and mining data from an area of underground coal mining in Garrett County, Maryland: Maryland Geological Survey Report of Investigations No. 41-A, 81 p.

Johnson, G.C., Zimmerman, T.M., Lindsey, B.D., and Gross, E.L., 2011, Factors affecting groundwater quality in the Valley and Ridge aquifers, eastern United States, 19932002: U.S. Geological Survey Scientific Investigations Report 2011-5115, 70 p. (also available online at http:// pubs.usgs.gov/sir/2011/5115/).

Kennen, J.G., and Ayers, M.A., 2002, Relation of environmental characteristics to the composition of aquatic assemblages along a gradient of urban land use in New Jersey, 1996-98: U.S. Geological Survey Water-Resources Investigations Report 02-4069, 77 p. (also available online at http://pubs. usgs.gov/wri/wri024069/).

Kennen, J.G., Henriksen, J.A., and Nieswand, S.P., 2007, Development of the Hydroecological Integrity Assessment Process for determining environmental flows for New Jersey streams: U.S. Geological Survey Scientific Investigations Report 2007-5206, 56 p. (also available online at http://pubs.usgs.gov/sir/2007/5206/).

Lindsey, B.D., Breen, K.J., Bilger, M.D., and Brightbill, R.A., 1998, Water quality in the Lower Susquehanna River Basin, Pennsylvania and Maryland, 1992-95: U.S. Geological Survey Circular 1168 (also available online at http://pubs. usgs.gov/circ/circ1168).

Lindsey, B.D., Falls, W.F., Ferrari, M.J., Zimmerman, T.M., Harned, D.A., Sadorf, E.M., and Chapman, M.J., 2006, Factors affecting occurrence and distribution of selected contaminants in ground water from selected areas in the Piedmont aquifer system, Eastern United States, 19932003: U.S. Geological Survey Scientific Investigations Report 2006-5104, 72 p. (also available online at http:// pubs.usgs.gov/sir/2006/5104/).

Lyford, F.P., Carlson, C.S., and Hansen, B.P., 2003, Delineation of water sources for public-supply wells in three fractured-bedrock aquifer systems in Massachusetts: U.S. Geological Survey Water-Resources Investigations Report 02-4290, 113 p. (also available online at http://pubs. usgs.gov/wri/wri024290/).

Mabee, S.B., 1999, Factors influencing well productivity in glaciated metamorphic rocks: Ground Water, v. 37, no. 1, p. 88-97, DOI: 10.1111/j.1745-6584.1999.tb00961.x.

Maidment, D., 2002, ArcHydro: GIS for water resources: Redlands, California, Environmental Systems Research Institute, Inc, 208 p. 
Markstrom, S.L., Niswonger, R.G., Regan, R.S., Prudic, D.E., and Barlow, P.M., 2008, GSFLOW-Coupled ground-water and surface-water flow model based on the integration of the Precipitation-Runoff Modeling System (PRMS) and the Modular Ground-Water Flow Model (MODFLOW-2005): U.S. Geological Survey Techniques and Methods 6-D1, 240 p. (also available online at http://pubs.usgs.gov/tm/ tm6d1/).

Maryland Department of Planning, 2010, Maryland State Data Center, accessed September 29, 2011 at http://www.mdp. state.md.us/msdc/projection/projectionsbyTopic.Shtml.

McSwain, K.B., Bolich, R.E., Chapman, M.J., and Huffman, B.A., 2009, Water-resources data and hydrogeologic setting at the Raleigh Hydrogeologic Research Station, Wake County, North Carolina, 2005-2007: U.S. Geological Survey Open-File Report 2008-1377, 48 p. (also available online only at http://pubs.usgs.gov/of/2008/1377/).

Meyer, G., and Beall, R.M., 1958, The water resources of Carroll and Frederick Counties: Maryland Department of Geology, Mines, and Water Resources Bulletin 22, 228 p.

Moore, R.B., Schwartz, G.E., Clark, S.F., Jr., Walsh, G.J., and Degnan, J.R., 2002, Factors related to well yield in the fractured-bedrock aquifer of New Hampshire: U.S. Geological Survey Professional Paper 1660, 51 p., 52 pls. (also available online at http://pubs.usgs.gov/pp/pp1660/).

Morgan, R.P., and Cushman, S.F., 2005, Urbanization effects on stream fish assemblages in Maryland, USA: Journal of the North American Benthological Society, v. 24, no. 3, p. 643-655, DOI: 10.1899/Y04-019.1.

Morgan, R.P., Kline, K.M., and Cushman, S.F., 2007, Relationships among nutrients, chloride and biological indices in urban Maryland streams: Urban Ecosystems, v. 10 , no. 2 , p. 153-166.

Nelms, D.L., and Moberg, R.M., Jr., 2010, Hydrogeology and groundwater availability in Clarke County, Virginia: U.S. Geological Survey Scientific Investigations Report 20105112, 119 p. (also available online at http://pubs.usgs.gov/ sir/2010/5112/).

Nelms, D.L., and Moberg, R.M., Jr., 2011, Preliminary assessment of the hydrogeology and groundwater availability in the metamorphic and siliciclastic fractured-rock aquifer systems of Warren County, Virginia: U.S. Geological Survey Scientific Investigations Report 2010-5190, 74 p. (also available online at http://pubs.usgs.gov/sir/2010/5190/).

Nutter, L.J., 1973, Hydrogeology of the carbonate rocks, Frederick and Hagerstown Valleys, Maryland: Maryland Geological Survey Report of Investigations No. 19, 70 p., 2 pls.
Nutter, L.J., 1975, Hydrogeology of the Triassic rocks of Maryland: Maryland Geological Survey Report of Investigations No. 26, 37 p., 1 pl.

Nutter, L.J., 1977, Ground-water resources of Harford County, Maryland: Maryland Geological Survey Bulletin 32, 44 p.

Nutter, L.J., and Otton, E.G., 1969, Ground-water occurrence in the Maryland Piedmont: Maryland Geological Survey Report of Investigations No. 10, 56 p., 1 pl.

Nutter, L.J., Smigaj, M.J., and Knobel, L.L., 1980, Garrett County water-well records, chemical-quality data, groundwater use, coal test-hole data and surface-water data, with a section on gas-well records: Maryland Geological Survey Basic Data Report 11, 102 p.

Olden, J.D., and Poff, N.L., 2003, Redundancy and the choice of hydrologic indices for characterizing streamflow regimes: River Research and Applications, v. 19, no. 2, p. 101-121, DOI: 10.1002/rra.700.

Otton, E.G., and Hilleary, J.T., 1985, Maryland springs-Their physical, thermal, and chemical characteristics: Maryland Geological Survey Report of Investigations No. 42, 151 p.

Otton, E.G., Willey, R.E., McGregor, R.A., Achmad, G., Hiortdahl, S.N., and Gerhart, J.M., 1988, Water resources and estimated effects of ground-water development, Cecil County, Maryland: Maryland Geological Survey Bulletin 34, 133 p., 6 pls.

Paillet, F.L., and Ollila, P.W., 1995, Identification, characterization, and analysis of hydraulically conductive fractures in granitic basement rocks, Millville, Massachusetts: U.S. Geological Survey Water-Resources Investigations Report 94-4185, 38 p. (also available online at http://pubs.usgs. gov/wri/1994/4185/report.pdf).

Parizek, R.R., and Siddiqui, S.H., 1970, Determining the sustained yields of wells in carbonate and fractured aquifers: Ground Water, v. 8, no. 5, p. 12-20.

Pinder, M.J., and Morgan, R.P., 1995, Interactions of $\mathrm{pH}$ and habitat on cyprinid distribution in Appalachian streams of Maryland: Transactions of the American Fisheries Society, v. 124 , no. 1, p. 94-102, DOI: 10.1577/1548-8659 (1995).

Poff, N.L., Allan, J.D., Bain, M.B., Karr, J.R., Prestegaard, K.L., Richter, B.D., Sparks, R.E., and Stromberg, J.C., 1997, The natural flow regime: A paradigm for river conservation and restoration: BioScience, v. 47, no. 11, p. 769-784.

Richter, B.D., Mathews, R., Harrison, D.L., and Wigington, R., 2003, Ecologically sustainable water management: Managing river flows for ecological integrity: Ecological Applications, v. 13, no. 1, p. 206-224. 
Ries, K.G., III, and Dillow, J.J.A., 2006, Magnitude and frequency of floods on nontidal streams in Delaware: U.S. Geolgical Survey Scientific Investigations Report 20065146, 57 p. (also available online at http://pubs.usgs.gov/ sir/2006/5146/).

Ries, K.G., III, Guthrie, J.G., Rea, A.H., Steeves, P.A., and Stewart, D.W., 2008, StreamStats: A water resources web application: U.S. Geological Survey Fact Sheet,20083067, 6 p. (also available online at http://pubs.usgs.gov/ $\left.f_{s} / 2008 / 3067 /\right)$.

Riggs, H.C., and Hardison, C.H., 1973, Storage analyses for water supply: U.S. Geological Survey Techniques of WaterResources Investigations, book 4, chap. B2, 20 p. (also available online at http://pubs.usgs.gov/twri/twri4b2/).

Rushton, K.R., and Chan, Y.K., 1976, Pumping test analysis when parameters vary with depth: Ground Water, v. 14, no. 2, p. 82-87.

Shapiro, A.M., Hsieh, P.A., Burton, W.C., and Walsh, G.J., 2007, Integrated multi-scale characterization of ground-water flow and chemical transport in fractured crystalline rock at the Mirror Lake Site, New Hampshire, in Hyndman, D.W., Day-Lewis, F.D., and Singha, K., eds., Subsurface hydrology: data integration for properties and processes: Washington, D.C., American Geophysical Union Monograph Series, v. 171, p. 201-225.

Slaughter, T.H., and Darling, J.M., 1962, The water resources of Allegany and Washington Counties: Maryland Geological Survey Bulletin 24, 408 p., 9 pls.

Soeder, D.J., and Kappel, W.M., 2009, Water resources and natural gas production from the Marcellus Shale: U.S. Geological Survey Fact Sheet 2009-3032, 6 p. (also available online at http://pubs.usgs.gov/fs/2009/3032/).

Southerland, M.T., Rogers, G.M., Kline, M.J., Morgan, R.P., Boward, D.M., Kazyak, P.F., Klauda, R.J., and Stranko, S.A., 2007, Improving biological indicators to better assess the condition of streams: Ecological Indicators, v. 7, no. 4, p. 751-767.

Susquehanna River Basin Commission, 2010, Natural gas well development in the Susquehanna River Basin: Susquehanna River Basin Commission Information Sheet, 4 p., accessed March 12, 2012 at www.srbc.net/programs/ projreviewnaturalgas.htm.

Starn, J.J., and Stone, J.R., 2005, Simulation of ground-water flow to assess geohydrologic factors and their effect on source-water areas for bedrock wells in Connecticut: U.S. Geological Survey Scientific Investigations Report 20045132,86 p., available online only at http://pubs.usgs.gov/ sir/2004/5132/.
Stranko, S.A., Hilderbrand, R.H., Morgan, R.P., Staley, M.W., Becker, A.J., Roseberry-Lincoln, A., Perry, E.S., and Jacobson, P.T., 2008, Brook trout declines with land cover and temperature changes in Maryland: North American Journal of Fisheries Management, v. 28, no. 4, p. $1,223-1,232$.

Strassberg, G., Jones, N.L., and Maidment, D., 2011, Arc Hydro Groundwater: GIS for hydrogeology: Redlands, California, ESRI Press, 160 p.

Swain, L.A., Mesko, T.O., and Hollyday, E.F., 2004, Summary of the hydrogeology of the Valley and Ridge, Blue Ridge, and Piedmont Physiographic Provinces in the Eastern United States: U.S. Geological Survey Professional Paper 1422-A, 23 p. (also available online at http://pubs.usgs.gov/ pp/pp1422A/PDF.htm).

The Nature Conservancy, 2008, Ecological limits of hydrologic alteration: Environmental flows for regional water management, accessed February 28, 2012 at $h t t p: / /$ www.conservationgateway.org/file/ecological-limitshydrologic-alteration-environmental-flows-regional-watermanagement.

Theis, C.V., 1935, The relation between the lowering of the piezometric surface and the rate and duration of discharge of a well using groundwater storage: Transactions of the American Geophysical Union, v. 16, p. 519-524.

Tiedeman, C.R., and Hsieh, P.A., 2001, Assessing an openwell aquifer test in fractured crystalline rock: Ground Water, v. 39, no. 1, p. 68-78.

Trapp, H., Jr., and Horn, M.A., 1997, Ground water atlas of the United States-Delaware, Maryland, New Jersey, North Carolina, Pennsylvania, Virginia, West Virginia: U.S. Geological Survey Hydrologic Investigations Atlas HA-730-L, 30 p. (also available online at $h t t p: / / p u b s . u s g s$. gov/ha/ha730/ch_l/index.html).

Turner-Peterson, C.E., and Smoot, J.P., 1985, New thoughts on facies relationships in the Triassic Stockton and Lockatong Formations, Pennsylvania and New Jersey, chapter 3 of Robinson, G.R., Jr., and Froelich, A.J., eds., 1985, in Proceedings of the Second U.S. Geological Survey Workshop on the early Mesozoic basins of the eastern United States: U.S. Geological Survey Circular 946, p. $10-17$.

Utz, R.M., Hilderbrand, R.H., and Boward, D.M., 2009, Identifying regional differences in threshold responses of aquatic invertebrates to land cover gradients: Ecological Indicators, v. 9 , no. 3, p. 556-567. 
van Tonder, G.J., Botha, J.F., Chiang, W.H., Kunstmann, H., and $\mathrm{Xu}, \mathrm{Y} ., 2001$, Estimation of the sustainable yields of boreholes in fractured rock formations: Journal of Hydrology, v. 241, nos. 1-2, p. 70-90 (also available online at $h t t p: / / d x$.doi.org/10.1016/S0022-1694(00)00369-3).

Waldron, M.C., and Archfield, S.A., 2006, Factors affecting firm yield and the estimation of firm yield for selected streamflow-dominated drinking-water-supply reservoirs in Massachusetts: U.S. Geological Survey Scientific Investigations Report 2006-5044, 39 p. (also available online at http://pubs.usgs.gov/sir/2006/5044/).

Willey, R.E., and Achmad, G., 1986, Simulation of groundwater flow and base flow in weathered crystalline rock, Upper Cattail Creek, Howard County, Maryland: Maryland Geological Survey Report of Investigations No. 45, 68 p.

Williams, J.H., Lane, J.W., Jr., Singha, K., and Haeni, F.P., 2002, Application of advanced geophysical logging methods in the characterization of a fractured-sedimentary bedrock aquifer, Ventura County, California: U.S. Geolgogical Survey Water-Resources Investigations Report 00-4083, 28 p., accessed February 28, 2012 at http://ny.water.usgs. gov/pubs/wri/wri004083/.

Williams, L.J., Kath, R.L., Crawford, T.J., and Chapman, M.J., 2005, Influence of geologic setting on ground-water availability in the Lawrenceville area, Gwinnett County, Georgia: U.S. Geological Survey Scientific Investigations Report 2005-5136, 43 p., available online only at $h t t p: / /$ pubs.usgs.gov/sir/2005/5136/.

Winter, T.C., Harvey, J.W., Franke, O.L., and Alley, W.M., 1998, Ground water and surface water-A single resource: U.S. Geological Survey Circular 1139, 79 p. (also available online at http://pubs.usgs.gov/circ/circ1139/).

Wolman, M.G., 2008, Water for Maryland's future: What we must do today: Final Report of the Advisory Committee on the Management and Protection of the State's Water Resources, [variously paged], accessed February 28, 2012 at http://www.mde.state.md.us/assets/document/ WolmanReport_Vol1.pdf and http://www.mde.state.md.us/ assets/document/WolmanReport_Vol2Appendices.pdf. 

Prepared by USGS West Trenton Publishing Service Center. Edited by Valerie M. Gaine.

Graphics and layout by Timothy W. Auer.

For additional information, contact:

Director, MD-DE-DC Water Science Center

U.S. Geological Survey

5522 Research Park Drive

Baltimore, MD 21228

or visit our Web site at:

http://md.water.usgs.gov 


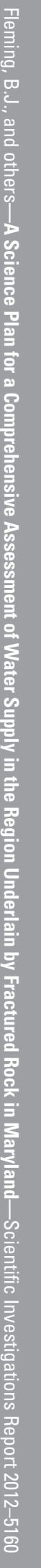

(3) Printed on recycled paper

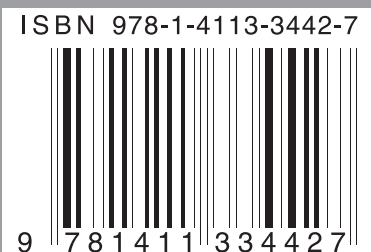

